\title{
The Curving Shore of Time and Space: Notes on the Prologue to Pushkin's Ruslan and Ludmila
}

\section{Citation}

Russell, James R. 2012. The Curving Shore of Time and Space: Notes on the Prologue to Pushkin's Ruslan and Ludmila. In Shoshannat Yaakov: Jewish and Iranian Studies in Honor of Yaakov Elman, ed. Shai Secunda and Steven Fine, 323-370. Leiden and Boston: Brill Academic Publishers.

\section{Published Version}

doi:10.1163/9789004235458_018

\section{Permanent link}

http://nrs.harvard.edu/urn-3:HUL.InstRepos:34257918

\section{Terms of Use}

This article was downloaded from Harvard University's DASH repository, and is made available under the terms and conditions applicable to Open Access Policy Articles, as set forth at http:// nrs.harvard.edu/urn-3:HUL.InstRepos:dash.current.terms-of-use\#OAP

\section{Share Your Story}

The Harvard community has made this article openly available.

Please share how this access benefits you. Submit a story.

\section{Accessibility}




\title{
THE CURVING SHORE OF TIME AND SPACE: \\ Notes on the Prologue to PUSHKIN's RUSLAN AND LUDMILA.
}

\author{
By James R. Russell, \\ Harvard University, \\ Cambridge, Mass.
}

Золотое руно, где же ты, золотое руно?

Всю дорогу шумели морские тяжёлые волны,

И, покинув корабль, натрудивший в морях полотно,

Одиссей возвратился, пространством и временем полный!

("Golden fleece, where are you now, golden fleece?

All the journey long roared the heavy sea waves,

And, leaving the ship that had worked a canvas of the seas,

Odysseus returned, replete with time and space!")

-Osip Mandelstam (1891-1938). ${ }^{1}$

"As lucid as you like or as deep as you choose to dive."

—Adam Gopnik, on the Alice books of Lewis Carroll. ${ }^{2}$

\section{PREFACE.}

On a muddy winter morning in 1967, a ninth-grader was standing in a noisy, crowded line at the cafeteria of the Bronx High School of Science, memorizing Mikhail Yur'evich Lermontov's poem “The Sail” («Парус») from a mimeograph handed out in Ms. Meisel’s first-year Russian class. An older boy ahead of him - a fearsome upperclassman — noticed, and, with a gentleness he never forgot, carefully wrote out for him in Russian script an enchanting poem about an oak by a curving shore, a learned cat, and a forest whose unknown paths bore the footprints of unseen beasts. The magic and beauty of Pushkin's poem, like first love, never left the boy as he grew into a man: beneath the playful verses he felt there was a great and powerful mystery. Most all Russians know every image in the Prologue to Ruslan and Ludmila; and I imagine many a reader has wondered what profundity of meaning lies beneath the limpid beauty of the light surface. (Pushkin's friend Küchelbecker thought Ruslan and Ludmila a lovely creation, but one without any substantial meaning.)

\footnotetext{
${ }^{1}$ Concluding lines of the poem «Золотистого мёда струя из бутылки текла...» (“Golden honey from the bottle streamed...”), 1917, in Осип Мандельштам, Стихотворения, Проза, Библиотека Поэта, Москва, 2001, с. 66 (Osip Mandelstam, Poems and Prose, Poet's Library, Moscow, 2001, p. 66). Mandelstam wrote this poem of his own Tristia ex Ponto at the dacha of S. Sudeikin in Alushta, on the Black Sea coast of the Crimea, where he had gone for a respite from the chaos of the Russian revolutions and civil war. As has been recognized, it is plainly inspired by these lines: Heureux, qui comme Ulysse, a fait un beau voyage,/Ou comme cestuy là qui conquit la toison, /Et puis est retourne, plein d'usage et raison, /Vivre entre ses parents le reste de son age! "Happy is he who, like Ulysses, has taken a beautiful journey/ Or like the one who has won the Golden Fleece, /And then returns full of experience and wisdom /To live with his parents the rest of his days." (Joachim du Bellay, $16^{\text {th }}$ cent., Les Regrets, sonnet no. 31 .) Perhaps the change from use and reason to time and space reflects Mandelstam's awareness of Einstein's thought. In Mandelstam's poem being away has a relativity: the outward journey to regain Helen and the return to Penelope are associated. So with du Bellay we have both the Odyssean nostos and the outward voyage of the Argo to Colchis, whose shores the same sea washes as Tauris.

${ }^{2}$ Gardner, p. xvii (see text 5.2 appended to the end of this article).
} 
This essay approaches that question, albeit with respect to the Prologue rather than the larger poem: Is there the possibility of a profound, symbolic, spiritually fulfilling meaning? One starts with a cursory survey of the history of the text, its literary context, and its reception; this is followed by a close reading. One then employs an illustration of the poem after Pushkin's death by the rather obscure artist Ramazanov to establish a visual structure, as though the poem were ekphrastic, travelling from left to right and up and down, onto the temporally sequential scene established by Pushkin: curving seashore at the beginning, i.e., on the left; oak, Cat, and Poet at center foreground, with an undine in the branches above; and mysterious forest on the right. Supernatural beings from Russian folklore and myth emerge from the sea and fly through the air, creating a vertical pattern to the Otherworld vision.

One then maps Ramazanov's illustration of 1843 in turn upon William Blake's painting of 1821, "The Sea of Time and Space". Neither Pushkin nor his illustrator is likely to have seen it, though Pushkin and Blake shared some interests and common traits: they liked Ossian and were interested in the epic and mythological heritage of their respective nations, they saw themselves as prophetic voices in the cast of Isaiah, and they were both irreverent, transgressive figures in their societies trying to invent a fundamentally new aesthetic. So far, though we deal with parallels rather than filiation, we are still securely situated in the contiguous environments of 19th-century Europe. But then, for the interpretation of Blake's painting, we must resort to material that, though very much more remote, is - one would plead — not at all irrelevant. This is where the New York high school boy deploys the weapons of the mature Orientalist.

Blake's sources for his painting, unlike Pushkin's for his poem, can be traced to various Neoplatonic texts of Late Antiquity, notably to Porphyry's De Antro Nympharum ("On the Cave of the Nymphs"), an esoteric interpretation of a mysterious image in the Odyssey of Homer; and from these it can be established that the English poet has evoked a vision of a place outside the normal continuum of time and space, a point of transit where some souls enter physical incarnation and others depart from this world on the journey to heaven. There is a Gnostic religion, Mandaeanism, most of whose adherents now live in southern Iraq and Iran whose founders, rebelling against the established Temple cult of Israel, settled to the immediate south and southeast of Armenia. In the third century a man named Patteg, a proto-Mandaean, and his wife Maryam Kamsarakan, whose name suggests Christian and Armenian connections, had a son they named Mani who went on to found the great Manichaean faith: apparently he had close Armenian associates and actively propagated his new religion in Armenia.

The layout and architecture of the Mandaean temple complex, the manda, explicitly embody the structure, symmetry, and symbolism - for concrete ritual purposes - of the painting by Blake. Such parallels, from the two antipodes of the Classical world, are striking, but not, ultimately, surprising: the ideological sources and casts of mind and imagination of Blake and his Gnostic precursors are in many respects kindred. Varied as the sources of Pushkin's mythological learning are, in folk tale, European poetry, and Old Russian epic, they are not Gnostic. The cosmic structure of the Prologue to Ruslan and Ludmila is his very own: he has come up with a Slavonic Cave of the Nymphs by the power of his own vision. There is his profundity; there, the mystery of his beautiful poem.

The second part of the essay explores the work of several visionary Russian writers after Pushkin: Vladimir Nabokov, Velimir Khlebnikov, and Daniil Kharms - who have been inspired by elements of the Prologue. They employ in their encounters with the poem new insights into the imagining of an Otherworld: "trans-rational" (Rus. zaum') and absurdist lexicons and thematic structures (inspired in part by the inventions, known to the Russians this time, of another Englishman, Lewis Carroll), non-Euclidian mathematics, intentionally supernatural connections, the mystical teaching known as Kabbala, and graphic experimentation (personal ciphers, and the enigmatic Voynich manuscript).

THE PROLOGUE TO RUSLAN AND LUDMILA. 
Pushkin's first great poema, ${ }^{3}$ Ruslan and Ludmila $(R L)$, was approved by the censor Timkovsky on 15 May 1820 and published in late July or early August 1820: he had begun it in 1817, while still a student at the Lycée of Tsarskoe Selo; and he read the completed text to friends at the end of March 1820. But before it appeared in print at St. Petersburg, the poet himself was exiled to south Russia and Moldavia; in July 1820, in the Caucasus, Pushkin composed a sad Epilogue in which he mourns the departure of poetic inspiration. $R L$ is the second-longest poetical work in the corpus of Pushkin's writings, after the "novel in verse" Evgenii Onegin: it consists of six Cantos of 2,822 lines in all, in iambic tetrameter. The sources from which Pushkin drew inspiration and background material are numerous: Ariosto's Orlando Furioso and Voltaire pervade the tone and spirit of the work; and Pushkin borrowed happily from the texts of Russian epic (the controversial Old Slavonic Slovo o polku Igoreve, "The Lay of Igor's Campaign", or, simply, the Igor' Tale), of folk tales (skazki), and of heroic ballads (called now byliny, a conscious neologism of Pushkin's day). He drew also from contemporary artistic treatments of these old and folk sources: Karamzin's Il'ya Muromets and Zhukovsky's ballads - especially "Rusalka of the Dnepr". Like many other Russian and European poets of his time, he was fascinated and moved by Macpherson's Ossian. The modern Irish novelist Colm Tóibín, in his foreword to the first full, book-length English edition and translation of $R L$, offers a vivid evocation of the contrary energies that find harmony in the poema, as in so much of Pushkin's oeuvre: "Pushkin thus came to the story of Ruslan and Lyudmila with all the ironies and sense of crafty distance which his education had offered him. He had the energy of a natural storyteller and the resources to usurp that energy... He managed what is almost unmanageable: to offer parody and enchantment at the same time. He offered the mock heroic without losing the heroic."4 This evaluation shares the Russian critical insight into Pushkin's “lightness" (лёгкость), by which is meant poetry whose playful gracefulness of style seems effortlessly to convey an extraordinary depth of meaning and feeling. Yuri Lotman has observed that $R L$ prepares the reader of Eugene Onegin for the irony and contrast of Pushkin's style. ${ }^{5}$

Zhukovsky's acclamation, "To a victorious pupil from a defeated master," has come to epitomize the immediate popularity and success of the poem amongst the Russian reading public. The first edition sold out at once, with some paying 25 rubles for a copy. Critical acclaim was to come somewhat later: some critics found $R L$ indecent, and I. Dmitriev, for example, wrote "A mother orders her daughter to spit upon this tale” («Мать дочери велит на сказку эту плюнуть»). Pushkin took all such insults to heart; so years later he replied, in Eugene Onegin, "Of course the mother would have ordered/ Her daughter to read his [works]” («Его [труды] конечно мать/ Велела б дочери читать»). Though the criticism was trivial in this case - the censor had approved $R L$ for publication, as noted above, and had done so without requiring any revisions or excisions - one has to notice the dark clouds gathering. Pushkin is the author of the Gavriiliada, an obscene parody of the Annunciation; his own "Exegi monumentum" is a blague, a practical joke, about Derzhavin's earlier ode; he called Falconet's equestrian statue of Peter I an idol (Rus. kumir) and aroused the ire of the Emperor. There must inhere in Pushkin's lightness and playfulness a tendency to intentional transgression that characterizes much artistic innovation but necessarily leads to confrontation with the established order and its canons of propriety and taste. Pushkin suffered ostracism, persecution, and death at the hand of d'Anthès, partly because of his own transgressive character, and that of his work. ${ }^{6}$

\footnotetext{
${ }^{3}$ The useful Russian word поэма has no exact English equivalent. It can be characterized as a composition in verse, verging on the scale of an epic in length, whose theme, however, is more that of a novel or romance.

${ }^{4}$ Roger Clarke, tr., Alexander Pushkin, Ruslan and Lyudmila, London: Hesperus, 2005, p. viii.

${ }^{5}$ Ю.М. Лотман, Пушкин, СПб: Искусство-СПб, 1997, с. 194: Yuri M. Lotman, Pushkin, St. Petersburg: Art-St. Petersburg, 1997, p. 194.

${ }^{6}$ Anthony Julius, a British lawyer, literary scholar, and art critic, offers a forensic exploration of the legal ambiguities of the frequent conflicts between artistic creativity and conventional morality in Transgressions: The Offences of Art, Chicago: University of Chicago Press, 2002. The aspect of sexual misconduct, in the artist's work or his life, seems to be a particularly frequent component of the confrontation. An artist's defiant response makes clear that the transgression is not an all-too-human peccadillo but an ideological stance and protest, and thereby makes the rift radical, sometimes tragic. The painter Thomas Eakins, whose use of nudity and whose possible homosexual leanings scandalized the prim academic establishment of the arts in Philadelphia, declared in 1894, "My honors are misunderstanding, persecution, and neglect, enhanced because unsought" (Julius, p. 44). That is, Eakins considered everything
} 
Pushkin composed the Prologue (text 1.1: «У лукоморья...», “Ву the bow-curve of the seashore...") to the poem late in 1824, during his sojourn at his estate at Mikhailovskoe in 1824-1826. On 12 October 1826 Pushkin read the Prologue and other compositions to a gathering of friends in Moscow at the home of D. Venevitinov; and in a memoir written forty years later M. Pogodin professed still to feel the excitement of that occasion. It was published in the second edition of $R L$ at Petersburg, 1828. The reviews of the new edition stressed the novelty, individuality, and originality of the Prologue, which sketched out, enthused the Moscow Telegraph, "a whole world of Russian tales presented by the hand of a great master of Russian realities and fantasies."7 The Epilogue, which, as noted above Pushkin had in fact written in 1820 , when he completed the body of $R L$, was also included with the text only in the second edition, though in 1820 it had been published separately. John Bayley wrote that $R L$ leaves the "feeling... of a society apprehending itself... in a sort of microcosmic idyll." " The Prologue evokes a microcosm of its own; and it is on it that this study focuses. Pushkin based the first part of the Prologue on one of his nursemaid Arina Rodionovna's tales, which he jotted down in his notes (text 1.2); and Bayley observed that in reworking the passage for his poem, Pushkin strove for the greatest conciseness, stripping the first line, for example, of the unnecessary verb stoit, "stands": the microcosm was to be as micro as possible. Pushkin pared his own draft down further, excising the adverb tam "there" (which will play a major, and contrastive, role in lines 7-29) and a whole extraneous line (I den' i noch' tam kot uchenyi/ Ne skhozhii ni s odnim kotom "And day and night there a learned cat/ Unlike any other cat there is"). ${ }^{10}$ The Prologue to $R L$ is not unique as an addition to a large work: Pushkin was to write one to Eugene Onegin" - but "By the bow-curve of the seashore" is an extraordinary, independent poem that merits discussion on its own. It is a powerfully compact work of visionary, mythological lyricism, and nothing decisively links it to the poem it introduces. Indeed it is at variance with the latter: Pushkin heard the tale from a "monastic chronicler" ( $R L$ V.225-228), not the Learned Cat of the Prologue. Lotman, noting the contrast between the Prologue and the rest of $R L$, seeks to explain how the poet might have justified to himself its inclusion in the second edition: "When working on $R L$, Pushkin was not yet able to penetrate the genuine world of Russian folklore as deeply as he could after his stay in Mikhailovskoe. However, in preparing the new edition the poet did not go about redoing his earlier poema. He introduced into it the excerpt 'By the bowcurve of the seashore...' and this illuminated the text in a new way, without changing it."12

The Prologue can be divided into three parts: the introductory lines 1-6 that set the scene; the main narrative and list, lines 7-29; and a coda partially recapitulating 1-6 but with an intrusive element. To the

he did natural and right. Two generations later, the Armenian poet Charents, a Pushkin scholar to be discussed in a note below in connection with the poem "The Prophet", was to be persecuted, then murdered by the puritanical Stalinist régime, whose disapproval he incurred not only by his work, but by his defiantly trangressive sexual behavior. Plus ça change...

${ }^{7}$ Московский телеграф, 1828, ч. 20, № 5, с. 78: «целый мир русских сказок, в эскизе представленный рукою великого мастера русских былей и небылиц.»

${ }^{8}$ John Bayley, Pushkin: A Comparative Commentary, Cambridge: Cambridge University Press, 1971, p. 49.

${ }^{9}$ Ibid., p. 51.

${ }^{10}$ Seе A.С. Пушкин, Полное собрание сочинений, т. 4, Москва: Изд. АН СССР, 1937, с. 276 («Черновой отрывок пролога»): A.S. Pushkin, Complete Works, vol. 4, Moscow: Publishing House of the Academy of Sciences of the USSR, 1937, p. 276 ("Draft excerpt of the Prologue").

11 «Разговор книгопродавца с поэтом», “The bookseller's conversation with the poet”: it should remind one of another series of prologues situated in ironic detachment outside the action of the work underscoring the artificiality of the latter. This is the prologue in Heaven (cf. the setting of the Biblical book of Job) and the prologue in the theater (cf. the play Shakuntala of Kalidasa) preceding the first part of Goethe's Faust. The Prologue to $R L$ is characterized, in contrast, not by an attitude of detachment, but by its opposite: an immersion in the mythological material that is, if anything, deeper than in the poema itself.

${ }^{12}$ Lotman, op. cit., p. 758: Работая над «Русланом и Людмилой», Пушкин ещё не обладал той мерой проникновения в подлинный мир русского фольклора, которая стала доступна ему после пребывания в Михайловском. Однако, готовя новое издание, поэт не стал переделывать свою раннюю поэму— он ввёл в неё синтезирующий фольклорные мотивы отрывок «У лукоморья дуб зелёный...», и это по-новому осветило текст, не меняя его. 
third part belongs a concluding couplet that serves in part as a transition to the body of the poem. The lexicon of the Prologue stands out, both from the rest of the work and from Pushkin's corpus in general: the characters come from Russian folklore, and some of them - Tsar' Kashchei, the witch Baba Yaga, a Learned Cat - appear only here. ${ }^{13}$ The Prologue is exceptionally, densely populous: ${ }^{14}$ between lines 1 and 29 we meet the Cat, the Forest Sprite, a Mermaid (Rusalka), beasts, a hut on chicken feet, thirty Knights, their Seaborn Sire, a Prince, a fearsome King, a Wizard, a Hero, a Princess, a Brown Wolf, the witch Baba Yaga, a walking mortar, and king Kashchei gloating over his gold. That makes fourteen named, more or less animate individual characters, plus the Knights, the unseen "people" (narod), and an unspecified number of unseen beasts whose tracks appear on unknown paths. The other verbal material of the passage is rich; but the word tam, "there", stands out for repetition: it is met fourteen times (corresponding, indeed, to the number of particular characters introduced), sure evidence that Pushkin intended his reader to regard the Prologue in part as a mythological list, reminiscent of the mnemonic tour de force of ancient epicHomer's catalogue of ships in the Iliad, for example. The provision of such a list establishes bardic mastery and authority.

It also creates an Otherworld strongly defined by the repeated adverb tam as separate from this world; and the dense foregrounding of mythological realia - Nabokov called it the "it-ness" of a story - is also a salient feature of the literature of fantasy. ${ }^{15}$ If one considers the Prologue as ekphrasis- a literary description of a picture - the hypothetical painting from which Pushkin worked would be a canvas full of characters on land, in the sea, and in the sky, with exemplifications of diverse opposites: faithful virtue (Princess and Brown Wolf) and degrading vice (the evil Kashchei with his golden hoard), or sorcery (Baba Yaga) and its overthrow (the Hero riding the vanquished Wizard). This is a magical world, so creatures that should be in one realm can appear in its reverse: Knights come out of the depths of the sea; but the aquatic Mermaid is seated high in a tree. This is not a forced effect: there are submarine knights, and the rusalki of Russian folk belief haunt the branches during the week of Rusalia, after the feast of the Trinity, to lure her victims to be tickled to death of drown in a watery grave. It enables one to see into places normally invisible, as one should expect of a cosmogram. (Pushkin plays on the roots ved- "know" and vid- "see", with their derivatives, as we shall see presently, to stress this perception of the marvelous.) And the whole should be anchored by the central image of the oak, the world tree where the Learned Cat reproduces the diurnal revolution of the heavenly spheres ( $i$ dnyom $i$ noch'yu: "by day and by night") on his literal catena aurea, literally spinning the tales and songs Pushkin is there to transcribe. ${ }^{16}$ This World Tree is the central

${ }^{13}$ The leshii, a forest sprite or hamadryad, appears once more in Pushkin's oeuvre — but in an autobiographical sketch that is more explanatory background to $R L$ than it is a different work: Не смотря на то, что всем окружающим нас строго было запрещено пугать нас ведьмами, лешими, домовыми, няньки все-таки иногда говорили о них между собою, "Even though it was strictly forbidden to those around us to frighten us with witches, forest sprites, and house spirits, the nannies still sometimes talked among themselves about them": see АН СССР, Ин-т языкознания, Словарь языка Пушкина, Москва: Госиздат иностранных и национальных словарей, 1957, т. 2, c. 479 s.v. (Academy of Sciences of the USSR, Institute of Linguistics, Dictionary of the Language of Pushkin, Moscow: State Publishing House of Foreign and National Languages, 1957, vol. 2, p. 479 s.v.). On Pushkin's word for the bow-curve of the seashore, lukomor'e, see vol. 2, p. 512 s.v. In his works, Pushkin used the word koldun "sorcerer" 17 times (including $R L$, I.280, where it is a koldun who has kidnapped the heroine); nevedomyi "unknown", 35 times but nevidannyi "unseen" only twice; rusalka "mermaid", 10 times and rusalochka (diminutive), three.

${ }^{14}$ See В.А. Кошелев, Первая книга Пушкина, Томск: Водолей, 1997, с. 199 (V.A. Koshelev, Pushkin's First Book, Tomsk: Aquarius, 1997, p. 199): "The condensed [Rus. sgushchënnoe] beginning anticipates as it were the world of Pushkin's tales, that were not yet created." The author also points out in support of his suggestion that in the Prologue Pushkin uses thrice the word skazka, "tale", which is found nowhere else in the poema.

${ }^{15}$ Adam Gopnik apud Gardner, p. xviii (see text 5.2).

${ }^{16}$ In one Russian folktale, «ходит по тому столбу учёный кот... вниз идёт- песни поёт, а вверх поднимается- сказки сказывает; голос его за три версты слышен» (“A Learned Cat walks at that pole... he goes down and sings songs; upwards he ascends, and recounts tales - his voice can be heard three versts away") (see А.Н. Афанасьев, Народнье русские сказки, т. 1, Москва, 1984, с. 287: A.N. Afanas'ev, Russian Folk Tales, vol. 1, Moscow, 1984, p. 287). In Derzhavin’s Царь-Девuиа (Tsar'Devitsa, 1812), «И по веткам птички райски/ Скакивал заморской кот» (“And along the branches, 
point where the poet brings everything invisible into plain view through the Logos of his imagination. ${ }^{17} \mathrm{~A}$ painting cannot reproduce one effect, indeed: everything except Pushkin himself is in motion. The poet alone sits immobile at the very center of the composition.

After line 30, Pushkin enters this magic cosmos, his own fictional landscape: between lines 30 and 35 , the personal pronoun "I", used five times ( $y a, 4 \mathrm{x}$; mne [dat. sg.] 1x), is the only animate inhabitant of the coda, save for the Learned Cat, who belongs to the opening scene that is being recapitulated. In the coda, all the verbs are $1^{\text {st }}$ pers. sg. past (byl "[I] was", pil "drank", videl "saw", sidel "sat") until the Cat's sole govoril ("he told me his tales"), after which the verbs are $1^{\text {st }}$ pers. again, but now, strikingly, in the present tense (ротпуи "I remember", povedayu "I shall relate"). The density of the usage of the pronoun serves, again, to stress the sudden and visible entry of the author. And the distribution of verbs symmetrically from past to present, to either side of the Cat's narration, suggests that Pushkin, the Cat's interpreter, forms a bridge between the mythological world in illo tempore and the present time of the literary public. The unity of time of the Prologue is difficulty to define and contrastive, which suggests an Otherworld quality of a great deal of time telescoped into a few sidereal moments. Pushkin recorded in his notebook that the "thirty splendid knights" («тридцать витязей прекрасных», who are to appear again in his Tale of Tsar Saltan) "are the same down to a hair in the timbre of their voices, their height, and their appearance; and they emerge from the sea for only one hour" («точь-в-точь ровны и голосом и волосом, а выходят они из моря только на один час»); in the poem this happens at dawn («о заре»). But the poet also avers that the Learned Cat recounted or spoke (Rus. govoril, in the habitual mode of the verb, as is pil, "drank", of the mead Pushkin there imbibed) its tales («сказки»), of which the narrator apparently remembers but one («одну я помню»); so there were more, and it all took much longer, then, than an hour. If the Learned Cat is standing in for Arina Rodionovna, then it is in fact all his early childhood that the poet telescopes into a single magic, radiant hour of dawn.

In the earlier section of the Prologue there is an incantatory, mantra-like couplet: tam na nevedomykh dorozhkakh/sledy nevidannykh zverei "there on unknown paths/ are the tracks of unseen beasts" with the assonant, Indo-European etymological figure ved-/vid-: in the coda, Pushkin annuls both negatives with videl "I saw"and povedayu "I shall relate": these link knowing to seeing. Both vid- "see"and ved- "know" come in Slavic from proto-Indo-European roots whose assonance goes back to the primordial figures of the poetics of that giant language family. The poet has become seer and teller of what was unknowable and unseen, bringing it to the outer, present world (Rus. svet), and to light (also svet). The poet's seeing and knowing of the invisible and the unknowable is underscored also in line 13, tam les $i$ dol videnii polny. The forest (les) looms darkly to the viewer's right in the composition of the scene; but no dale $(d o l)$ has yet been mentioned, though the two form a nice, traditional figure. They are full of what Roger Clarke translates as "wraiths"; but viden'e/videnie, on the evidence of Pushkin's own usage, might be more precisely translated simply as "vision". The reference seems to be as much to phantasms one beholds in the dream state as to the prophetic or theophanic vision. ${ }^{18}$

paradisiacal birds-/ Loped the Cat from Beyond the Seas"). Pushkin seems to have opted for a cat who like a planet circumambulates the oak to stress the tree's centrality, rather than go up and down or run through the branches - where, in any case, the undine is seated.

${ }^{17}$ Koshelev, op. cit., p. 200, notes that in 1820 Pushkin traveled in the company of General N.N. Raevsky through the Pridneprovsko-Azovskaya steppe: in those parts there still stands the Zaporozhskii dub, "Zaporozh'e oak", which received sacrifices in ancient times. It was a place where Cossacks gathered for councils, and is still sacred in Ukrainian tradition (see В.Д. Михайлов, «К локализации пушкинского лукоморья,» Временник Пушкинской Комиссии, вып. 26, СПб, 1995, с. 192-196: V.D. Mikhailov, "Towards a localization of Pushkin's lukomor'e," Bulletin of the Pushkin Commission, no. 26, St. Petersburg, 1995, pp. 192-196).

${ }^{18}$ In the Словарь языка Пушкина (Dictionary of the Language of Pushkin), s.v., are these citations: Германн... записал свое видение (Hermann... wrote down his vision); Тут он видит чудное виденье: на помосте валяются трупы (Now he saw a weird vision: corpses lay strewn on the platform); Однажды утром Чарский чувствовал то благодатное расположение духа, когда мечтания явственно рисуются перед вами, и вы обретаете живые, неожиданные слова для воплощения видений наших... (Once in the morning Charsky experienced that blissful disposition when one sees one's dreams sketched plainly before one, and acquires vivid, unexpected words with which to embody our visions...); ... в неясных 
Either way, the poet sees and describes alertly, where others cannot; and this is precisely the quality of the prophet. In his poem of 1826 "The Prophet" (Пророк), Pushkin uses images drawn directly from the Biblical book of Isaiah to describe his painful transformation into a seer: his eyes and ears are changed, and he is able to perceive the tingle of heaven, the flight of angels, the tread of monsters beneath the sea, and the growth of the vine in the dale («дольней лозы прозябанье»). ${ }^{19}$ That is, Pushkin sees and hears things in heaven, on earth, and below the sea that are invisible and inaudible to mere mortals- just as in the Prologue. The link between the situation of the poet as seer in this poem and his self-identification with Isaiah in "The Prophet" is of interest because, as we shall see presently, it is precisely Isaiah who occupies the same compositional place as Pushkin, in a painting whose general structure and wealth of mythological detail closely parallel the Prologue: William Blake's "The Sea of Time and Space".

Another collocation to the figure neved-/nevid- in the Prologue can be cited from Pushkin's most powerful work of Russian social and historical mythopoesis ${ }^{20}$, that archetypal poema of St. Petersburg, The Bronze Horseman (Медный всадник), 1833. Peter the Great (d. 1725), founder of Russia's “window on Europe" (he did not think to pound a door through the wall), stands on the shore of the "barren waves" («на

видениях первосония (... in those unclear visions one has when dropping off to sleep); На рассвете она задремала, но тонкий сон её был встревожен печальными видениями (She finally fell asleep at dawn, but her light slumber was disturbed by gloomy visions). Pushkin refers here to the conscious, waking dream, Rus. мечта, the dream in sleep, Rus. сон, and the intermediate state. A salient feature of Homer's strange, supernatural cave of the nymphs at Ithaka, to be discussed presently, is that it has two entrancesone for gods and one for mortals - and shortly after Odysseus arrives there, is entertained by Eumaios, and finds his way to Penelope, the latter explains to him that dreams have two gates: prophetic ones (i.e., divine ones) come through gates of horn, while false (i.e. personal, circumscribed, mortal) ones emerge through gates of ivory (Odyssey 19.562-565). There is a correlation here, structural and thematic, that is too obvious to ignore, of the point of entry of dreams and that of gods or souls. One scene is that of the meeting of the two worlds; the other, of the consciousness of the two. So with his use of videnie Pushkin intimates an oneiric state in which his mythopoetic landscape is perceived. On Pushkin's use of themes and images of dreams, and of their subsequent employment in Russian literature, notably in Gogol's absurdist writing foreshadowing Kharms, see Michael R. Katz, Dreams and the Unconscious in Nineteenth-Century Russian Fiction, Hanover, NH: University Press of New England, 1984.

19 The Soviet Armenian poet Ełišē Č'arenc' (Yeghishe Charents), 1897-1937, loved Pushkin; and an unpublished translation of the poem, entitled in Armenian Margare, "(The) Prophet", together with a kind of fugue based upon it, are found in his MSS. See J.R. Russell, "Ch'arents" the Prophet," Journal of the Society for Armenian Studies 11 (2000), pp. 11-38, repr. in J.R. Russell, Armenian and Iranian Studies, Harvard Armenian Texts and Studies 9, Cambridge, MA, 2004, pp. 1073-1099. It is worth noting, in connection with the collocation of William Blake's painting "The Sea of Time and Space" and the Prologue to $R L$ in this essay, that Bayley in his monograph on Pushkin (op. cit., p. 145), compares «Пророк» ("The Prophet") to Blake's "Hear the Voice of the Bard", the first poem of Songs of Experience. ${ }^{20}$ The scene of the poema is the disastrous flood of 7 November 1824: Pushkin in the text speaks of Peter's having founded a city under the sea, and thereby connects Petropolis to Atlantis as a place of hubris, divine wrath, doom, death, and enduring mystery. Since Petersburg itself survived both this inundation and another exactly a century later, the Neva becomes in the work of later poets the locus of mystery and dark kingdom of Persephone. That did not stop Mikhail Dmitriev from imagining in his poem «Подводный город» ("The City Under the Sea"), 1847, a descendant of the fisherman Peter saw mooring his boat to all that is left of Petersburg: the point of the Admiralty spire protruding from the waters (see В.В. Яковлев, Петербург в русской поэзии XVIII-первой четверти ХХ века, СПб: Филфак СПбГУ, 2002, с. 185186: V.V. Yakovlev, ed., Petersburg in Russian Poetry, from the 18th Century to the First Quarter of the 20th Century, St. Petersburg: Faculty of Philology of St. Petersburg State University, 2002, pp. 185-186). Evgenii, a poor young clerk of noble ancestry ruined by the flood curses Falconet's equestrian statue of Peter, and the idol (кумир, kumir: Nicholas I disliked the implication and struck the word from Pushkin's MS.), detaching itself from its pedestal, pursues the crazed wretch to his death. In one stroke, Pushkin created the two dominating myths of the city: that of supernatural malevolence and that of the alienated man or "man from underground" (разночинец, человек из подполья, и т.п.) — that animate the uneasy visions of Gogol, Dostoyevsky, and their successors down to the present day. 
берегу пустынных волн») of the Neva, where a sad Finnish fisherman casts his nets. Here and there behind the monarch, wooden huts loom black here and there («чернели избы здесь и там») — "and the wood, unknown to the rays/ of the sun hidden in fog/ soughed roundabout" («и лес, неведомый лучам/ в тумане спрятанного солнца/ кругом шумел»). The tripartite spatial and thematic composition of this opening scene of the work: river or sea (the emperor stands at the place where the great river flows into the Gulf of Finland), central motionless figure in a space with marginal structures, mysterious forestcorresponds grosso modo to that of the Prologue to RL. Here instead of nevid- "unseen" Pushkin has employed the verb spryat- "hide", preserving the long, sonorous form, though, of a passive participial form in four leisurely syllables: spryátannogo. The poet perhaps intends by having the sun's visage hidden rather than merely unseen to introduce the sinister note of Divine disfavor that will swell as the city founded by the demonic autocrator is whelmed in dark floodwaters. The dark coloration distinguishes this poem sharply from the sunlit dawn of the Prologue to $R L$. The negative feeling of alienation and unease is intensified in other ways, too: one observes that the inhabitants of the gloomy landscape in this prologue to The Bronze Horseman are all non-Russians (финский рыболов, убог(ий) чухон(е)ц: "Finnish fisherman", "impoverished Finn"), in sharp contrast to the happy profusion of Slavonic creatures in the Prologue to RL: Peter, the Westernizing king, is building his new capital in an alien place!

The meaning of the word svet in the line povedayu teper' ya svetu should perhaps be limited here in the strict sense to high society - members of the Arzamas club, the customers of Smirdin's Petersburg bookshop, Pushkin's friends. He does not seem to expect for this light work, at this early stage of his life, the cosmic reading public of Exegi monumentum, "all Great Russia, and every tongue there spoken". But that was the public he actually did get — and svet still has also the broader meanings "world" and "light". In a prophetic poem about the fate of the world composed between 1910 and 1914, Golos iz khora, "A Voice from the Chorus", Alexander Blok speaks of the kholod i mrak gryadushchikh dnei, "the cold and murk [thanks for this elegant correspondence to V.V. Nabokov] of the days to come" and the insane whirling of the planets. The poem has the famous line Vsyo budet chernee strashnyi svet, "All blacker will shine the awful light." Though light cannot be dark save in the poetic imagination, and the image of the world and of planets pervades Blok's poem, the contrary image is still achieved in part because the primary meaning of svet is "light". ${ }^{21}$ One presses this observation because Pushkin is making the unseen visible, bringing it to light. The material of lines 1-29 of the Prologue to $R L$ is unseen, not only because it belongs to a mythic Otherworld, but also because it belongs to the heroic age of the past, cf. the couplet from Ossian that was the original prologue and in the second edition precedes the first Canto: Dela davno minuvshikh dnei,/ Predan'ya stariny glubokoi, "Deeds of days long gone,/ Traditions of deep antiquity."

This invocation of Slavonic antiquity by a bard setting out to recount a heroic poem should remind one of a particular monument of the Russian heroic era, the Slovo o polku Igoreve: Pushkin begins the Prologue with the memorable words $u$ lukomor'ya "by the bow-curve of the seashore", a phrase he uses nowhere else; ${ }^{22}$ but the Igor' Tale does contains a similar phrase, iz luku morya, which Nabokov identifies

\footnotetext{
${ }^{21}$ The English tr. of this line in Mochulsky's Blok renders svet as "world", one of its two meanings, but this is definitely wrong. I doubted my intuitive understanding of the meaning of the word as "light" (cf. the Hermetic nyktelios, "nocturnal Sun", used notably by the Romantic poet Gérard de Nerval in his "El Desdichado") and polled a number of Russian friends at random. They all read the word as "light", not "world". However there may still be an implicit contrast with the standard Rus. expression for the whole wide world, belyi svet, lit. "the white world". But note Mandelstam's phrase «ночного солнца не заметишь ты», "you will not notice the nocturnal sun", and, a bit farther afield but still illustrative of the poetic capacity to enflesh impossible contradictions, these lines from the song "Gates of Eden": "Of war and peace the truth just twists/ Its curfew gull just glides/ Upon four-legged forest clouds/ The cowboy angel rides/ With his candle lit into the sun/ Though its glow is waxed in black/ All except when 'neath the trees of Eden" (Bob Dylan, Lyrics, 1962-1985, New York: Knopf, 1985, p. 174). One recalls also George Seferis' verse, Angeliko kai mauro, phôs "Angelic and black, light".

${ }^{22}$ См. Словарь языка Пушкина, т. 2, с. 479 (Dictionary of the Language of Pushkin, vol. 2, p. 479) s.v.; this also places the action firmly in ancient Russian epic time, and indeed in RL, I.57 (p. 7) he mentions the bard Bayan. It is worth noting in passing that the hermit Ruslan encounters who has failed in love as
} 
with a bend of the Sea of Azov (called Surozh in the epic) at the mouth of the river Don. ${ }^{23}$ The poet's plunge into glubokaya starina takes him to the first pamyatnik, the first monumentum, of Russian literature itself: it is an assertion of his comparable stature. So Pushkin has not only crossed between worlds- from one svet to the high Svet of St. Petersburg ${ }^{24}$ - he has also conquered Time.

The coda contains one element that is not in the initial stanza of green oak and Learned Cat, and it is so casually introduced as to induce the reader to suppose the poet is concealing its novelty - a device that serves to focus one's attention more keenly. I tam ya byl, i myod ya pil, "And there I was, and the mead I drank." What mead? We have been told nothing of it hitherto, though the heroes will drink it in I.96. Russian folktales often end with a requisite draught of mead; so the "and... and" could mean merely that Pushkin did that too, did everything that is expected in the conclusion of a tale. Who gives the cup to Pushkin, the Cat? The Rusalka? Baba Yaga, as she tilts past in her mortar? Or is this some divine potation, the very stuff of prophetic and poetic intoxication, gushing out of a dimension beyond even that of the sprites and witches? It is not the grape wine of Biblical climes, either, this drink - nor, indeed, the Bordeaux of Eugene Onegin's soirées - but honey-based, northern Indo-European stuff: the madhu- of Vedic India and Iran, that with which the earliest Greek was methysmenos, "intoxicated". The stressed appearance of the author's persona with potation, at least, is an intrusive element in the coda: Pushkin wants one to notice he has been there. He is an Isaiah-like prophet, a new voice in Russian poetry and life, the fulcrum and demiurge of his mythic cosmos, an Odysseus who has mastered space and time.

\section{UT PICTURA POESIS.}

In 1843 , the year after the completion of Mikhail Glinka's opera $R L$, N.A. Ramazanov illustrated the Prologue (plate 1). ${ }^{25}$ The oak, elevated on a hillock at the center of the composition, its branches spreading to either edge, balances and knits together a very intricate, busy picture and draws the viewer's attention to Pushkin and the Learned Cat. The Rusalka on her branch, the captive Princess and Brown Wolf on the left in the foreground, and king Kashchei on the right, form a light triangle pointing upwards, of immortal, mythopoetic hyper-realities, superimposed symmetrically against the dark, funnel-like, downward-pointing triangle of the oak, which has its roots in the black earth, the Slavonic mat'syra zemlya, source of the living-and-dying generations of leaves (and, metaphorically, of men). The purpose of this arrangement is, again, to center poet and cat. On the viewer's left is the curving seashore, with the knights emerging from the waters and the prince in the air above them. On the shore, to the right of the tree and just before the forest begins, are Baba Yaga's mortar, the wooden hut on chicken legs, and so on. The hut is originally in folk belief the witch's; and it stands "as though on the invisible boundary between

shepherd, hero, and wizard (pastukh, geroi, koldun), recapitulates the Indo-European social triad of herdsman, warrior, and priest.

${ }^{23}$ Vladimir Nabokov, The Song of Igor's Campaign: An Epic of the Twelfth Century, New York: McGraw Hill, 1960, p. 113, n. on line 366. In the "Lament of the Women of Rus"” in the text of the Slovo: «... взмути рьки и озеры; иссуши потоки и болота, а поганого Кобяка изъ луку моря от жельзныхъ великыхъ пльковъ половецкыхъ яко вихръ, выторже» cit. by Edward L. Keenan, Josef Dobrovský and the Origins of the Igor' Tale, Cambridge, MA: Harvard Ukrainian Research Institute/ Davis Center for Russian and Eurasian Studies, 2003, p. 279 f. Keenan, whose monograph is intended to prove that the ancient Russian epic is in fact an inspired forgery based by a late- $18^{\text {th }}$-century Moravian Slavicist on other epic poems, notes that the phrase luka morya appears thrice in the Zadonshchina and in the Slavonic text of the Wisdom of Ahiqar (Povest' ob Akire premudrom) with which the MS. of the Slovo was bound. Dahl, S.v., explains the lukomorskie polovtsy as steppe-dwellers (Pechenegs, Polovetsians) of the Azov littoral.

${ }^{24}$ Pushkin finished $R L$ on 26 March 1820. In mid-April the government learned of his political verses ("Freedom", "To Chaadayev", etc.); and rumor had it he was to be exiled to the far northern monastery of Solovki. But on 6 May of that year the poet was ordered from the capital to the South of Russia instead. He was not to enjoy the high society of Petersburg again for seven years.

${ }^{25}$ Seе Министерство культуры РСФСР, Всесоюзный музей А.С. Пушкин: Каталог, МоскваЛенинград: Госиздат «Искусство», 1957, с. 45, 271 (Ministry of Culture of the RSFSR, All-Union Museum of A.S. Pushkin: Catalogue, Moscow-Leningrad: “Art” State Publishing House, 1957, pp. 45, 271). 
Home and Forest and was a special 'liminal' point for entry into the otherworld of folktale". ${ }^{26}$ Thus, a horizontal tripartite analysis yields sea to the left, land with a world-tree and the center and liminal space to the right, and the dark forest to the far right.

If one approaches the picture using the vertical schema of reversed and superimposed triangular patterns, Ramazanov's own poetics of composition has, subtly and most certainly unwittingly, also reproduced the schema of a common and very important Hindu yantra. The latter, a Sanskrit term meaning something like "mechanism", is the graphic counterpart of the mantra - the latter means hieros logos, a word or sound of not only semantic value but intrinsic power. Some yantras are made for protective, thaumaturgic, or healing purposes; when they are cosmic maps, or mandalas (lit. "circle"), they are intended for meditation (dhyana). A mandala always has a central point (bindu) representing primordial consciousness (chitta); and if mantras are written on a yantra, then the seed syllable (bija-akshara) is placed on the bindu. Ramazanov's yantra is the six-pointed star consisting of two intersecting figures: a light upward-pointing triangle (trikona), generally symbolic of the male lingam principle, against the dark downward-pointing triangle that represents the female principle, the yoni. The yantra expresses the balance and harmony of the multifarious powers in the universe of male and female, life and death, good and evil, light and darkness. Pushkin, the Russian kavi ("poet-seer") and his guru ("teacher") Cat are bindu and bijaakshara: the center, capable of poetic perception and creative consciousness, that generates the whole through the logos - poet as poietes, "maker", in the literal sense. ${ }^{27}$ When Andrei Sinyavsky noted Pushkin's lightness, or when Bayley characterized $R L$ as a balanced mixture of the heroic and the profane, they perceived, this very cosmic clarity and symmetry, the serene and playful profundity of Pushkin's lyric. The mythic geography of the Prologue invites comparison with two parallel, graphic schemata. Both have a serious religious and philosophical character, which sets them apart in intention from the Russian work; but the boundaries between secular and profane may be violated when discussing mythopoesis, even when it is as self conscious and even parodic as Pushkin's.

\section{WILLIAM BLAKE’S PAINTING.}

One may compare to Ramazanov's ink-and-watercolor illustration, with its horizontal and vertical patterns, a painting dated 1821 by the English visionary poet and artist William Blake, The Sea of Time and Space (plate 2). The picture is strikingly similar in both general composition and particular details. There is a populous seascape to the left; a tree in the foreground center with a human figure nearby whose singularity and importance is indicated by the unique use of red color in his vestments; and more figures and an obscure cave on the right. It is also extremely and intricately busy, a cosmically huge vista of land and sea full of humans, animals, mythological beings, and magical objects. It even has a watery sprite entangling a man. The painting is a microcosmic allegory, but of what? Kathleen Raine suggested that Blake was trying to represent the cosmic process of apogenesis and genesis: the descent of the soul into the material world, its fate here, and its ascent at death into spiritual rebirth. She argued that Blake's source was the treatise De antro nympharum by the Neoplatonic philosopher Porphyry: "On the Cave of the Nymphs" is an allusion to the grotto at Ithaka where Odysseus stored his treasures at his homecoming, in the Odyssey of Homer. Following several mysterious allusions in the epic itself, the ancient interpreters, regarding the Homeric text as a kind of sacred scripture, suggested that the grotto was an allegory of this world, a place where fate was spun, whose two entrances represented the points where souls entered the material world (genesis) and departed from it (apogenesis). ${ }^{28}$ Raine's suggestion did not at first gain general scholarly acceptance; but recently Christopher Heppner has averred that Raine, even if she

\footnotetext{
${ }^{26}$ В.Л. Пропп, Исторические корни волшебной сказки, Ленинград, 1986, с. 58-64 (V.L. Propp, Historical Roots of the Magical Folktale, Leningrad, 1986, pp. 58-64), cit. by Koshelev, op. cit:: «как бы на невидимой грани между Домом и Лесом и было особенным 'пограничным' пунктом для входа в сказочный, потусторонний мир».

${ }^{27}$ See S.K. Ramachandra Rao, Yantras, Delhi: Sri Satguru Publications, 1988, pp. 12-16. I am grateful to Dennis E. Cordell for a copy of this book.

${ }^{28}$ See Odyssey 13.96-112 for a description of the grotto, which is by an olive tree (cf. the дуб зелёный) on the shore of the semi-circular bay (лукоморье!) of Phorkys, the Old Man of the Sea (дядя морской!) at Ithaka. Thomas Taylor's (1758-1835) translation of Porphyry, On the Cave of the Nymphs, was reprinted with an introduction by Kathleen Raine, by Phanes Press, Grand Rapids, MI, 1991.
} 
overstressed a particular text whose details did not correspond with satisfactory exactitude to those of the painting, was at least on the right track. The Sea of Time and Space, in his view, treats a Neoplatonic theme and portrays the human life cycle, but draws its inspiration from multiple sources, including Thomas Taylor's translations and commentaries on Plato and Ovid's Metamorphoses. He also argues that the man painted boldly in red is the Biblical prophet Isaiah: Blake has combined the characters and symbolism of different cosmologies, with a view to exalt Scripture and condemn paganism. ${ }^{29}$ But Blake also refers in his poema, Milton, to the sea of time and space after which the painting is named (text 2.3): the English epic poet tragically descends thither, and sees the noble giant Albion, who personifies the sacred essence of England, stretched out there in death. Blake was, like Pushkin, very fond of Ossian, the native British epic. The cosmology of the painting may, thus, combine not only Classical and Biblical material, but Blake's own mythopoetic Albion as well. A few remarks on the aspects of Neoplatonism that might have attracted Blake most strongly are in order here.

It may fairly be said that although Plato regarded the world as a legitimate entity, a part of the great chain of being, physicality is nevertheless an inferior state to that of pure spirit. Consequently the sojourn of the human soul during the term of the physical life of the body is the result of a descent from a true and happier home. The meaning of our existence, so replete with suffering, is to be understood as a hard schooling and purification preparatory to re-ascent to the realms of our origin. The world is a kind of penitentiary (Gk. phylakē); and death is liberation if it follows a virtuous life. The Neoplatonist school emerged in the early Christian centuries, reflecting both a trend towards religiosity and spirituality in philosophical speculation itself, and a pagan encounter with the Christian faith. Another, related set of movements of religious thought in the period comes under the rubric of Gnosticism. Arthur Darby Nock saw the various trends of Late Antique religious speculation conveniently (and, by orthodox Christians, disparagingly) termed Gnosticism as an extreme, even deranged, form of Platonism, in which the sleep and forgetting of this life is not so much a trial to be endured as a deception to be overcome. Where Platonism situates the world low on a chain of being but still regards it as valid, the Gnostics tend to a radical dualism: the world is bad and was created by a devil who has deceived his unlucky prisoners into thinking he is a god. The world is not a hard but just penitentiary: it is a concentration camp run by a deranged cosmic sadist.

Gnostic thinking is revolutionary kat' exokhen, since of necessity it must reformulate the worldaffirming cosmology of the canonical religion that serves as its substrate in such a way as to demonize and overturn the creator-god of that previous creed. Though the third-century Neoplatonist philosopher Plotinus famously disparaged the Gnostics as rejecting the very universe to which they belonged, the Neoplatonists nonetheless did regard physical genesis as a tragedy; and apogenesis, as the true soul-birth. Blake's contemporary William Wordsworth, and other Romantic poets who had access to the same translations of the Neoplatonists as Blake, seem to have rediscovered the Gnostic ideology and the revolutionary sentiment that was inseparable from it, and so relevant to the spirit of their own age. A salient feature of Gnostic mythology is the introduction of a dense crowd of divine and demonic beings whose names derive from heterogeneous sources, and who inhabit a spiritual world whose imaginal geography is superimposed upon the template of an intimately familiar earthly one. We have already seen how Blake could combine Neoplatonic, Biblical, and sui generis local, British imagery. He took an engraving of the Classical sculpture of Laocoön and his sons being smothered by serpents, and re-interpreted it as Jehovah flanked by Adam and Seth, surrounding the picture with dense graffiti proclaiming the truth of Hebrew art and decrying its Greco-Roman usurpation. Such inversion and co-optation of pre-existing material is typical of any new religion, but it is especially common in Gnostic writings.

William Blake's propensity to make up his own supernatural beings had as its proximate inspiration, as E.P. Thompson argued, the tradition of revolutionary, dissident personal visions cultivated by Protestant sectarians, particularly the Muggletonians of the $17^{\text {th }}$ century. The same sectarians are the ancestors of a more structured and socialized new religion, Mormonism, that came into being in northern New York state in Blake's (and Pushkin's) lifetime. Blake's spiritual places and beings are fuse Biblical,

\footnotetext{
${ }^{29}$ The painting "The Sea of Time and Space", 1821, was made with pen and ink, watercolor and gouache on gesso ground on paper. It is reproduced, with discussion of Heppner's analysis, in Robin Hamlyn and Michael Phillips, eds., William Blake, NY: Abrams, 2000, pp. 192-193 and pl. 240
} 
British, and imagined, glossolalic names. At this juncture, let us note some coincidences: Pushkin creates a similarly dense landscape to Blake's; and he populates it with his own, local Slavic mythical beings, much as Blake uses Albionic material: both were interested in their national mythologies and were inspired by Ossian. Though Pushkin identifies himself as the central figure in his composition, he regards himself, as Blake does, as a prophet in the mold of Isaiah (who seems to be the man in red in Blake's painting). As one has seen in the epigraph to this essay, Osip Mandelstam, the most uncannily Pushkinian of modern Russian poets, who wrote also a poem on Ossian, makes Odysseus himself the Sea of Time and Space, returning after his otherworldly wanderings to the Cave of the Nymphs!

THE MANDAEAN CONNECTION.

One has likened Blake's religious and artistic creativity to the activities of the ancient Gnostics; and in adducing for closer comparison as a test case a discrete Gnostic system - a defined religion based on Gnostic ideology — we shall see a striking and illuminating parallel to Pushkin's Prologue.

Although it might be thought that Gnosticism, a fundamentally transgressive rebellion against the world-affirming stance of a pre-existing religion, should be opposed to any establishment or institution as part of the problem or deception it seeks to remedy, in fact there were in Late Antiquity at least two established Gnostic religious institutions: the Mandaean religion, and Manichaeism, which originated from it. The third-century religious reformer Mānī (the name seems to mean "vessel", to which was appended Aramaic do hayye, "of life", hence "Manichaeus") was born in Arsacid Mesopotamia to a man named Pattēg, who followed the cult of the Mughtașila (Arabic, "those who baptize themselves", i.e., the Mandaeans, as we shall see presently), and a woman Maryam (i.e., Mary) of the noble Parthian clan of the Kāmsārakān, which was well established in Armenia. Christianity in Armenia boasts of origins in the mission of the Apostles Thaddeus and Bartholomew. Though the Apostolic legend is strongly mythologized, it is at least indisputable that the practice of the faith in Armenia long predates the conversion in the early fourth century by St. Gregory the Illuminator of king Tiridates the Great. Given her Christian name, it is thus at least possible Mānī was the son of an Armenian mother. A list of his writings mentions two Epistles to the Armenians; a Manichaean Apostolic narrative may be a recasting of an Armenian Christian Apostolic legend; and one of Mān̄̄ss companions at the time of his martyrdom was a man bearing a name, Bāt, that is best attested in Armenian. Manichaeism certainly existed in Armenia thereafter, though it became a catch-all term for heresy in Christian polemic. Even so, the Paulician, $\mathrm{T}^{\prime}$ 'ondrakite, and later heresies that flourished on the Armenian plateau have a distinctly Manichaean/Gnostic flavor to them.

Mānī created a complex, multi-tiered Gnostic cosmogony and cosmology, in which he created some beings and borrowed many others from Christianity, Zoroastrianism, and Buddhism, averring that the followers of these religions had misunderstood and corrupted the original revelations of their prophetic founders. It was probably this strategy of re-interpretation of pre-existing teachings that earned the Manichaeans the designation zandīg, "explicator" in Middle Persian, which was maintained into the mediaeval period in the Near East, cf. the Arabic loan zandīq, pl. zanädiqa. Of course the seventh-century Arab religious reformer, Muhammad, was to do much the same thing, presenting his new Scripture-inverse, the Qur'ān ("Call"), not as an innovation, but as a clear ( $m u b \bar{\imath} n$ ) exposition of the truths of the Old and New Testaments that the Jews and Christians had muddied over time. The Manichaean strategy was parasitical: in the West, the translators of its scriptures gave their work a pseudo-Christian cast; in China, the same teachings were phrased in such a manner as to make the Buddhist element predominant. Cultural variation may account for some of this; but, given the malignant effect of Manichaeism on the earlier faith communities it infiltrated, one might better liken the process to the adaptation of a virus to a host it is invading. It is noteworthy that the one prominent, revealed religion of antiquity that Mānī made no attempt to co-opt was Judaism. Though Gershom Scholem perceived a Gnostic aspect in Kabbala, an internal mystical trend in Judaism of uncertain beginnings, the Manichaeans hated rootedly the pro-cosmic Creator God, the teleological history of the nation of Israel, and the Temple cult of Jerusalem. Part of the reason for this seems to be that the cult of the abovementioned Mughtașila came into being precisely through a radical rejection of and rebellion against Second Temple Judaism. 
Though Manichaeism is long dead, the sect to which Pattēg adhered still survives, as the religion of the small Mandaean community of southern Iraq and Iran. The Aramaic designation manda '(də hayye $)$, "knowledge (of life)" (Mandaic Aramaic manda d hiia), is an obvious equivalent of Gk. gnōsis itself, with the mention of life familiar from the second element of the name of Manichaeism, though it has been suggested that the Mandaic word manda is a loan from Persian meaning "dwelling". ${ }^{30}$ According to native tradition, the early members of the community fled to a mountain in Media - northwestern Iran - they named Harran gawaitha ("the Inner"), ${ }^{31}$ in the days of king Ardban, i.e., in the Arsacid period. The foundation of their faith is belief that the creative and sustaining force of the universe is the Great Life, which comes to us through the waters of the Yardna, i.e., Jordan - this and other Biblical references in Mandaean cosmology suggest their ancestors were native to the Land of Israel. But, as one may expect of the precursors of Mānī, Mandaean Gnosticism radically inverts the religion of the Chosen People: a Hebrew name of God, Adonai, in Mandaean designates the melka, "king", of darkness; and, scandalously, Mandaeans commemorate in mourning the wicked host of the pursuing Egyptians whom God drowned in the Red Sea in the Exodus! $!^{32}$ The Mandaeans employ a form of Aramaic script peculiar to themselves: it is employed talismanically, and each letter possesses a symbolic value. A salient feature of Mandaean manuscripts is the employment of vividly angular line drawings of sacred beings, objects, and scenes. It is a tradition that cherishes, as the Manichaeans did, long poetical texts, mysterious spells, calligraphic writing, and the production of graphic art. William Blake would have found it most congenial. The complex of Mandaean cosmology and mythology presents a richly heterogeneous plethora of beings, from the gods and heroes of ancient Iran (e.g., Bahrām, the yazata VərəӨrayna of the Avesta; and the Saka hero Rostam familiar from the Šăh-nāme of Ferdōsī) to the Egyptian creator-god with Hebrew divine suffix, Ptahil. That is, where William Blake lodges an individual creative protest against the Creator God of the establishment of the Age of Enlightenment, whom he calls Urizen (i.e., "your Reason") and shapes a cosmology within his aesthetic craft, drawing from diverse sources, the Mandaeans do all this as an established religious system. So when Blake paints a cosmic painting of the sea of time and space, with tree and prophet and cave, expressing Neoplatonic and other values, one might hope to find a Mandaean parallel. And it is found, indeed, as a concrete object, as no less that the central locus of the principal rituals of Mandaean life and faith.

The name of the Mandaean temple complex in the literary language is mashkhana, lit. "dwelling place". ${ }^{33}$ This is, of course, none other than the Aramaic equivalent of Hebrew mishkan, a designation of the holy Temple at Jerusalem. In common Mandaic the place is called simply the manda (plate 3), as though it embodied everything essential to the Mandaean system. (It is noteworthy that the manda $\underline{d}$ hiia is often represented as a great tree: cf. the tree at the center foreground of Blake's painting, and Pushkin's green oak.) The manda is a hut enclosed by a fence within a sacred precinct. Only priests may enter the building itself. It must be constructed near a source of "living" water, i.e., a yardna. Two channels - one flowing in; the other, out - from the latter are dug, forming a bow-curve in front of the cult building. The manda is, correspondingly, the place where the rites of the soul's earthly genesis and apogenesis are consecrated: the former being the baptism whose prominence is indicated by the early Arabic designation of the sect; the latter, the liturgy of masiqta ("ascension") performed at death. The enfranchised soul travels North over the great white mountain Sur, up past the guard-houses (mataratha) of the imprisoning planetary demons to Ptahil: it boards a ship of light and travels across a kind of celestial Styx to the shores of the worlds of light and bliss from which it originally came before the descent into matter. ${ }^{34}$

\footnotetext{
${ }^{30}$ See E.S. Drower, The Mandaeans of Iraq and Iran, Leiden: Brill, 1962, p. 10.

${ }^{31}$ The "outer" Harran would be the ancient city of Abraham's sojourn, which lies a few miles south of the ancient Syro-Armenian stronghold of Christianity, Edessa (modern Urfa, in Turkey). For centuries Harran was the center of the Neoplatonizing, Gnostic Sabian religion, whose connections to the Mandaean faith are numerous and obvious. So many of the early Mandaeans lived in regions contiguous to, or overlapping, Armenia and territories inhabited by Armenians, on the south and southeast: Maryam's Kamsarakan kinsmen would thus have been likely to encounter them.

${ }^{32}$ Drower, pp. 76, 89.

${ }^{33}$ Ibid., p. 10.

${ }^{34}$ Ibid., pp. 123-125, 197-199.
} 
Since William Blake and the Mandaeans worked from kindred sources of inspiration - the Neoplatonism of his De antro nympharum is not remote in time or ideological and religious orientation from the Gnostic movements of the Second Temple period in Israel and the Arsacid period in Armenia and Parthian Mesopotamia - it is not surprising that their visions of the geographic particulars of the meetingpoint of the spiritual and material worlds should, mutatis mutandis, coincide. There is no documentation to suggest that Pushkin saw Blake's painting; and it is equally certain he was innocent of the intricacies of Mandaean orthopraxy. Yet his Prologue has its curving seashore, sacred tree, a kind of precinct, and all sorts of beings coming in and out of the Otherworld. In the middle is the human figure observing or controlling it all: Blake's Prophet, the Mandaeans' Priest, Pushkin himself.

In considering the Russian poem, one must concede that we deal with coincidence. C.G. Jung might have preferred the term synchronicity - his acausal connecting principle - to coincidence; and perhaps he would have adduced the Pushkinian correspondence as an example of the operation of an archetypal pattern of the collective unconscious. Pace the critics of Jung's methodologies: though scholarship is defined by methods depending upon argument from material evidence and must exclude therefore the inherently supernatural categories of synchronicity and archetype, it is also, on the same grounds, not possible for a scholar to reject outright the possibility that synchronicity, archetypes, and the supernatural may in fact exist, even if they cannot be adduced in a study of this kind. ${ }^{35}$ It is, however, reasonable to propose that Pushkin, in a manner parallel to Blake and the Gnostics, employed a "poetics of composition" (the term belongs to the Russian Structuralist Boris Uspensky) in which the various symmetries of the scene: curve of sea, space of shore, dark line of forest; central tree and author, drawing in the viewer; the sense of entrance and exit at the meeting point of the mythological and the quotidian - have a pleasing harmony that observant human inhabitants of the same world (with seas, trees, forests) are likely to represent in much the same way, whether for ritual (Mandaeans), a painting (Blake, Ramazanov), or a poem (Pushkin).

It is time now to consider the effect the Prologue, or elements of it, exerted upon some visionary Russian writers after Pushkin; and how they developed these themes. The image of the Polaris-bound Mandaean soul, freed from the body and rocketing over a great white mountain, reminds one of the memorable confusion of white fountain and mountain, the punning misprint not nonsense but a web of sense, in the near-death experiences recounted in the novel Pale Fire of Nabokov.

\section{After Pushinin 1: NABOKOVIANA.}

Vladimir Nabokov completed another work by Pushkin, the unfinished drama Rusalka (1832). The Rusalka-Mermaid is the mythological creature mentioned in the Prologue; so the striking appearance of Pushkin in the poem is the element that surely inspired Nabokov's final line in his completion of Rusalka, where the poet is made abruptly, even absurdly, to appear with mildly comic alliteration: «Пушкин пожимает плечами»P Pushkin pozhimaet plechami, "Pushkin shrugs his shoulders." 36 In his first

\footnotetext{
${ }^{35}$ However one must stress that if an artist reads Jung's books, for instance, it is merely perverse not to acquaint oneself with Jung's ideas when studying and interpreting the artist's work. It is worth quoting in this connection the important observation of James Elkins, On the Strange Place of Religion in Contemporary Art, NY: Routledge, 2004, p. 52: "The difference between the art studied in universities and the wider world of art practices can almost be defined by the acceptance, or rejection, of Jung. Inside academia scholars make use of Lacan and other post-Freudians; outside it, and in studio practice, people read Jung and Joseph Campbell."

${ }^{36}$ One should note, in addition to the obvious alliteration with the initial $p$-, the subtler employment in all three words of an affricate series: $\check{s}-z ̌ c ̌ c . ~ C f$. Nabokov's cunning alliteration of the cluster $g n$ - in the following note. Nabokov published his addition under his nom de plume Sirin in Новыци Журнал (The New Journal), NY, 1942.2, pp. 181-184: see discussion by J.R. Russell, "A Scholium on Coleridge and an Armenian Demon,” J. of the Soc. for Armenian Sts. 10 (1998, 1999 [2000]), p. 70 n. 24, repr. in J.R. Russell, Armenian and Iranian Studies, Harvard Armenian Texts and Studies 9, Cambridge, MA, 2004, p. 996. From their correspondence we know that Edmund Wilson expected that Nabokov would provide an unorthodox ending to Rusalka; but Nabokov responded, in a slightly condescending, didactic way, that Pushkin would not have done so. An ineluctable quality of Pushkin is lightness and richness without
} 
novel in English written in America, Bend Sinister, Nabokov enters the narrative at the end and allows the hero, Adam Krug, to see him. This intervention reaches farther in thematic effect than Pushkin's, since Nabokov's authorial entrance allows his character to discern a transcendent reality beyond the firing squad within the fiction. ${ }^{37}$ But it is reasonable to suppose that the Prologue inspired it. As Jane Grayson has noted, Nabokov in his completion of the drama drew upon mermaid tales going back to Classical myth and prehistory. The myth of the mermaid, who avenges love betrayed by luring victims down to her watery realm, evokes themes important to Nabokov: lost treasures, kingdoms, people. It is a tale also of metamorphosis, of communication between two worlds. ${ }^{38}$ The topos of submersion, like that of ascension, can be used to evoke transit from this world to the next, which Nabokov believed conceals a meaningful symmetry we are to discover. So he uses the image to describe a point of literary criticism, in Pale Fire (Library of America ed., p. 444): "Actually, it turns to be beautifully accurate when you once make the plunge and compel yourself to open your eyes in the limpid depths under its confused surface."

In the seventh chapter of the novel Bend Sinister, which Nabokov had originally intended to call The Man from Porlock, with a nod to the locus classicus of a vision interrupted, Coleridge's "Kubla Khan", there is a scholarly fantasia in which Ophelia, the Russalka letheana, or Mermaid of Lethe, floats in the waters of a Coleridgean river god Alpheus; and her lover Hamlet's mirror-double is Telmah, i.e., Telemachus: another prince in search of a lost father. (This is an early example of the use of meaningful looking-glass words to multiply realities and evoke potustoronnost', "Otherworldliness", that Nabokov was later to employ in Pale Fire.) It is plain that Nabokov had Pushkinian rusalki in mind for many reasons; but one can also prove that the mermaid of the Prologue to $R L$ in particular was of importance to him. The center of Pnin is the Joycean "Pninsday" chapter, in which through the citation in a Russian class of Pushkin's poem of 1829, Brozhu li ya vdol' ulits shumnykh, ("Whether I wander down noisy streets...") and other machinations, the author links the chronology of Pnin's own life to the fateful dates of Pushkin's. This is preceded by the visit of Pnin's estranged wife, Liza, a cruel and shallow woman whose poems are obscene (and hilarious) parodies of Anna Akhmatova's lyrics - the verses enraged Akhmatova when she learnt of them. ${ }^{39}$ Pnin is the opposite of Liza in every way: his love and telepathic empathy with their son Victor (this is a reprise of the Hamlet/Telemachus theme) is in contrast to her neglect; his loyalty and kindness are brighter against the background of her callousness. Liza is a cheap imitator of Akhmatova; Pnin shares an occult connection to Pushkin himself. After Liza leaves, the distraught, despairing, lost Pnin

innovation or, sometimes, even sublime content. But what Nabokov leaves unsaid in the exchange is that he considers "Pushkin shrugs his shoulders" to be within the bounds of Russian classical conventionality. So the basis for this conviction has to be its precedent, this Prologue.

${ }^{37}$ Nabokov adumbrated this effect in an earlier novel written in Russian, Приглашение на казнь (Invitation to a Beheading), where the hero Cincinnatus simply walks away from the scene of his execution and through the flimsy fabric of the fictional reality, towards a world inhabited by people like him. Since he has been accused by a ludicrous totalitarian tyranny of gnoseologicheskaya gnusnost' ("gnostical turpitude") for being insufficiently transparent, one must conclude that he is headed for what is to him the Otherworld - and for the reader, this sublunar world - in which his libertarian, individualistic creator dwells. Nabokov would have noticed that in $R L$ the Rusalka provides a wonderful Otherworld for a knight whom Ruslan hurls into the Dnieper: «... И слышно было, что Рогдая/ Тех вод русалка молодая/ На хладны перси приняла/ И, жадно витязя лобзая,/На дно со смехом увлекла,/ И долго после, ночью темной/ Бродя близ тихих берегов,/ Богатыря призрак огромный/ Пугал пустынных рыбаков» (А.С. Пушкин, Полн. собр. соч., т. 4, с. 36= РЛ 2.496-504: A.S. Pushkin, Complete Works, vol. 4, p. 36= RL 2.496-504) "And it was heard that Rogdai/ A young mermaid of those waters took/ To her cold bosom/ And, covering the hero with greedy kisses/ Conducted him away in laughter to the bottom,/ And long after of a dark night/ The knight's gigantic shade/ Wandering near the quiet banks/ Did frighten lonesome fishermen."

${ }^{38}$ See Jane Grayson, "Rusalka and the Person from Porlock," in Arnold McMillin, ed., Symbolism and After: Essays on Russian Poetry in Honour of Georgette Donchin, London: Bristol Classical Press, 1992, p. 171 .

${ }^{39}$ She should not have taken umbrage. The Russian equivalent of Lewis Carroll's parody, "How doth the little crocodile..." in Nabokov's translation of Alice in Wonderland is a parody, too - but of "God's little bird no labor knows, no care..." in Pushkin's The Gypsies! On the influence of Carroll's "Jabberwocky" on Daniil Kharms, see text 5. 
sits crying in his American landlady's kitchen: Joan tries to distract him with ads in a magazine, one of which shows a sailor, cat, and mermaid on a desert island. The sailor's thought-balloon converts the semihuman, semi-ichthyic rusalka into a full woman; the cat's, into a whole fish. But the marooned sailor is perhaps an intrusion of Pnin, who is called the "water-father" at various points in the book. Is the shipwrecked feline a certain Learned Cat? If so, then Pushkin, communicating astrally across the poshlost' ("vulgarity") of American consumer culture, is telling Pnin that it's all right. You are not lost. I'm here in the poem, and so are you - as me. As noted above, the fates of the two will become similarly merged in the next chapter of Pnin, through Nabokov's manipulation of dates.

It seems to me that Nabokov perceived in Pushkin's lightness the liberating, luminous hope of his potustoronnost'. In one stanza of $R L$, the kidnapped Ludmila decides to commit suicide by drowning- in the original plan, Nabokov's "My Poor Pnin", the water-father, was to kill himself — but doesn't. Early on Pninsday, the hero teaches the poem in which Pushkin wonders where death will find him: $v$ boyu li, $v$ stranstvii, v volnakh "in battle, wandering, or waves" - and this strophe is repeated in a reverie towards the end. The triplet: V volnakh reshilas' utonut',/ Odnako $v$ vody ne prygnula/ I dale prodolzhala put' (II.351-353, p. 32) "She decided to drown in the waves/ But did not jump into the waters/ And continued on her way." And the following stanza ends with and even more playful, resumptive triplet, to stress the cheerful lightness of the heroine's essential nature: Ne stanu est', ne budu slushat',/ Umru sredi tvoikh sadov!/ Podumala - i stala kushat' (II.375-377, p. 32) "I shall not dine, I shall not heed:/ I'll die here in your gardens!/ She thought, and thereupon began to eat." Nabokov, who noticed that volshebnik, "sorcerer", was a partial anagram of his name and encoded it into his ars poetica, the poem "Fame" («Слава»), must have delighted in the wittily Voltairean and quite disingenuous avowal by Pushkin, the greater magician, in RL: Ya kazhdyi den', vosstav ot sna,/ Blagodaryu serdechno Boga/ za to, chto v nashi vremena/ Volshebnikov ne tak uzh mnogo (IV.1-4, p. 50) "Every day, arising from sleep/ I give heartfelt thanks to God/ That in our times/ There aren't very many sorcerers."

Another of Nabokov's concerns, allied to the problems of the Otherworld, of memory and loss, and of preternatural affinity, was that of time. Speak, Memory begins with a disquisition on it; ${ }^{40}$ and towards the end of his earthly life the writer had Van Veen append an essay on it to Ada. Pushkin, as one has suggested above, managed to transcend time in his Prologue. The rusalka, by appearing seated in a tree, is a markedly Russian mermaid, different from the undines of other European folkloric traditions. But she also serves as an emblem of the poet's unique ability imaginatively to command the two worlds, to transform both, and to effect their intercommunication. The seated rusalka prefigures the seated Pushkin. His introduction of her is homage to Zhukovsky, whose ballad inspired Pushkin's; and Nabokov in his time further refracted with characteristic cunning the sorcery of his predecessors.

\section{AfTER PushKin 2: INTO THE FifTh Dimension WITH KHLEBNIKOV AND KHARMS.}

The aspect of glossolalia that one finds in the poetry of William Blake: the invention of names or words that are phonetically impressive but often nonsensical or only para-semantic, like mantras-is of particular importance when one considers how poets of the $20^{\text {th }}$ century were to encounter Pushkin's mythopoesis and craft their own. The creative manipulation of sound and speech, whether to express the

${ }^{40}$ Nabokov mentions a friend who had a particular horror of films made before his own birth, for they depicted a world going about its business utterly without his existence. (After our death, we are not so entirely absent, since some remember us, and our deeds leave their traces and effects.) It is certain that Nabokov knew the writer and poet Delmore Schwartz: the latter wrote about the former's work in correspondence with the editor of the publishing house New Directions; and Mrs. Mary Kennedy of Cambridge, Mass., who was then married to the Faulkner scholar Prof. Calvert Collins, recalled to me that Schwartz and Nabokov were often in the same company as evening guests at her home near the Harvard campus during World War II. So one wonders whether Nabokov ever read Schwartz's short story, "In Dreams Begin Responsibilities", in which the narrator dreams he is seated in a cinema watching a film of his parents' courtship. He jumps up from his seat to shout: his horror does not come, though, from a perception of his previous nonexistence, but from a desire never to have been born. It is no new sentiment. Areion me einai, the Greeks averred; and W.S. Burroughs used latterly to quote with approval the Mexican adage, "The worst mistake is to have been born." 
personal apperception of a religious reality that normal language is inadequate to represent, or to shape a new and mythopoetic literary vision, is common to early Christians and Gnostics, and to Russian Futurians and absurdists, including two whose work is particularly indebted to Pushkin's Prologue to RL, Velimir Khlebnikov and Daniil Kharms. The latter in particular acknowledges a debt to Lewis Carroll, the author of the poem "Jabberwocky" - which has been invoked, in turn, to describe the operations of ancient religion! One can, in other words, reasonably adduce ancient Near Eastern religious data in the attempt to understand ostensibly secular poetry of recent times. ${ }^{41}$ We shall discuss a Russian Futurian transmutation of the landscape of the Prologue to $R L$, one in which time is made into a concrete object. So it is apposite to mention that one of Blake's likely sources, the $18^{\text {th }}$-century English Neoplatonist Thomas Taylor, has a rather tactile evocation of time that could have informed the image of water in Blake's painting: "Even time, with restlesse motion, slides away/ Like living streames. "42 If one juxtaposes the pictures by Ramazanov and Blake, the curvature of the shore of Pushkin's lyric may be not only Arina Rodionovna's traditional incipit to a skazka, but also a concrete evocation of time, in which the circle of repetition and the linearity of change merge as a curve, a bow.

But it is Velimir Khlebnikov who first reflects in subsequent Russian poetry on this possible facet of Pushkin's work: the reduction of the temporal to a mere dimension like those of space - the creation of a landscape of which the space-time continuum is but a component. The creatures and setting of the Prologue to $R L$ are diffused through several poems and prose pieces (texts 2.1-6) written around 1907 by the budetnik "Futurian", who evokes concisely a higher-dimensional, poetically envisioned universe through neologisms in which such abstractions as time and feeling are made into concrete objects: beings fly on grustyl'ya, "sorrow-wings" (2.6); a vidyaz' "seer-knight" (2.3) accomplishes his quests; and the landscape is dominated by vremysh "time-grass" (2.1). The mead is that vechnosti vino, "wine of eternity", particular to Russia (2.4); and the Rusalka (2.2) expands from a mythical creature into a being who incorporates also the homonymic seasonal festival Rosalia. Pushkin's izbushka receives a neologistic epithet, vremataya, "made of time, chronish"; the forest itself is vremovoi, "timeful". As for the "Russian spirit" Pushkin extols in the Prologue (though playfully undermining Baba Yaga's sinister taste for Russians to eat), Khlebnikov underscores and celebrates the etymological link between the Slavs, slava "glory", and slovo "word, epic, lay" (2.5). Strangely, and coincidentally, the present-day British writer Scarlett Thomas within her novel The End of Mr. Y has composed a sonnet as Prologue to an imaginary work on an Otherworld. This Prologue begins with the evocation of a "time-wrought" seashore; and its structure parallels in important ways that of Pushkin's poem, through Khlebnikov's lens (see text 6.1). Thomas does share some interests, at least, with another Russian poet who revisited Pushkin's curving seashore: the absurdist Daniil Kharms.

Kharms (text 4.1) wrote two versions of a poem beginning with the line «Надо кикать лукоморье» ("The curving shore [lukomor'e] deserves a coo"). The shorter and earlier version is in his fourth notebook, dated 18 August-30 September 1925, in 34 lines on two pages. The incipit is pure Pushkinian mythopoesis: the use of the word лукоморье in the very first line is sufficient to show thisbut with the simultaneous introduction of a rare but venerable verb from the Slavonic epic antiquity of the Igor' Tale that so interested Pushkin: кикать (kikat'). It is to be employed twice as an infinitive $(1.1,13)$, once in a form of the 3rd pers. pres. (кикает, 1. 22), and once as a perf. ppart. reflexive (накикавшись, 1.14). It is onomatopoeic, used of the call of a bird (e.g., «кичет лебедь белая», "the white swan cries"; in the Igor' Tale, Yaroslavna «зегзицею кычет» “coos like a cuckoo"); ${ }^{43}$ and it appears in the standard Russian dictionary of Dahl (II, p. 107) immediately before the entry on кикимора, kikimora. This is a juxtaposition Kharms is unlikely to have failed to notice. For this is the name of a Russian mythical house spirit who lives invisibly behind the stove by day and emerges at night to make mischief with looms and spindles. One who sees her spinning will die, so it is likely these instruments retain their ancient significance as symbols of fate. Variants of the name of this creature include кика and кыка, so a

${ }^{41}$ See the citations of Patricia Cox Miller, Morton Smith, and Hart Crane in the discussion of "Jabberwocky", texts 5.1, 5.2.

42 Thomas Taylor, Works of Plato, II, 672, cit. by Christopher Heppner, Reading Blake's designs, Cambridge: Cambridge University Press, 1995, p. 250.

${ }^{43}$ Edward Keenan, op. cit., pp. 243, 258, provides a list of ten birds in the epic, for whose song nine different verbs are used. The zegzitsa, "cuckoo" (modern Rus. kukushka) uses kykati (modern kikat'). 
derivation from кикать is at least possible (the element mora/mara means by itself an illusory vision or sprite. If the kikimora is the "mara who cries (kikaet/kichet/kychet)", though, then the derivation would have to do with a sound rather than the bird-like appearance of other mythical, siren-like beings such as the Sirin or Gamayun. For the kikimora appears as a woman with long, flowing hair: she is sometimes thought to be the wife of the male house spirit, the domovoi. The kikimora likes not only settled habitations, but empty houses as well; and she can be introduced into a new dwelling under construction by vengeful carpenters - who put a sort of little voodoo doll in the foundations - if the builder is stingy with the vodka! ${ }^{44}$

The mythical creature kikimora makes a brief appearance, in fact, in a play based upon the Prologue to RL. Yulii Kim, whose bardic songs were popular among the Soviet generation of the 1960's and later, published recently a play, "Rusalka on the Branches: A Pushkinian Tale", 45 in which Zhora, a New Russian thug who owns a holding company called Lukomor'e and plans to open a sort of Russian Disneyland, accompanies Sasha (i.e., Alexander Pushkin) to the real otherworld Lukomor'e in search of a mermaid for a sideshow. To underscore the role in Russian culture of the new kleptocracy, the author makes Zhora the latter-day catamite d'Anthès, who murders Sasha but ends up as the transgendered fake of his own freak show. Kim takes careful note of all the points where Pushkin has departed from the formulae of the folktale: of the unexpectedly brown wolf, for instance, this colloquy: "Sashka: He isn't gray. He's brown. Zhora: Brown means it's a bear, Sanya.” (Р. 378: «Сашка: Он не серый- он бурый. Жора: Бурый- это медведь, Саня.») Where Pushkin has the innocent, exultant "There is the Russian spiritthere is Russia's scent!" and Baba Yaga perambulates on the land in her mortar, Kim restores the Slavonic equivalent of a real witch's threatening, cannibalistic "Fee, fie, foe, fum! I smell the blood of an Englishman!” (p. 416: «Фу, фу... здесь русский дух... здесь Русью пахнет», “Foo, foo... there’s a Russian spirit/scent... it smells here of Rus'."). In a nod to the masterpiece of 20th-century Russian mythopoesis, Mikhail Sergeyevich Bulgakov's novel The Master and Margarita, the Learned Cat introduces himself by the name of Woland's feline assistant, Behemoth (p. 374). So, on p. 379, the Wolf calls the noxious Zhora a "swamp demon" (kikimora bolotnaya). Kim writes in a literature permanently suffused in Pushkin's charm, where Kharms has joined the stream of poetry loved and recited; so the appearance in this intricately self-conscious play of the kikimora may be the imprint of the echo of a Kharmsian bird whose kikat' at the curving shore itself echoes both Pushkin and the archaic monument of the Igor' Tale.

The mixture of magical and folkloric resonances in a word reaching back to the beginnings of Russian poetry, together with the power and symbolism of its onomatopoeic sound, would have multiply appealed to Kharms: the word kikat' would have lain on a boundary between the actual and the unseen, between the semantic and zaum', rather like the obscure English words Lewis Carroll, whose work Kharms read and liked, resurrected as neologisms in his compactly mythopoetic crypto-epic "Jabberwocky". Did Kharms realize the layered powers of his terminology? Since he uses kikat' so often in so many forms, it means at least that he concentrated on the word - so perhaps he did. But as Lewis Carroll remarked in a letter of 1896 to young readers, "Words mean more than we mean to express when we use them."

The rhythm of Kharms' poem, the phrase «из за острова» (“out from the isle"), and the reference to Pechenegs, summon other old themes of Russian folk and epic culture: the ballad of Sten'ka Razin, and the Polovtsy/Pechenegs of the Igor' Tale. The mention of Alyonka (Аленю, 1. 15) refers to the genre of the Russian folk tale, or skazka; and Alexander, "half Asia", the Minotaur, Phoenicia, and an Isle of Darkness, belong to the fantasia of the Alexander Romance, with its panoply of mythical monsters, miraculous locomotion, and adventures in remote, fabulous climes. Ammon may refer to the Egyptian god reputed to

\footnotetext{
${ }^{44}$ See Русский демонологический словарь, сост. Т.А. Новичкова, СПб: Петербургский писатель, 1995, c. 210-218 (T.A. Novichkova, ed., Russian demonological dictionary, St. Petersburg: Petersburg Writer, 1995, pp. 210-218), s.v.; W.F. Ryan, The Batthouse at Midnight: An Historical Survey of Magic and Divination in Russia, University Park, PA: Pennsylvania State University Press, 1999, pp. 43, 227; Linda J. Ivanits, Russian Folk Belief, Armonk, NY: M.E. Sharpe, 1989, p. 57.

45 Юлий Ким, «Русалка на ветвях: Пушкинская сказка», Моя матушка Россия, Москва: Время, 2003, c. 362-440: Yulii Kim, "Rusalka on the Branches”, My Mother Russia, Moscow: Time, 2003, pp. 362-440.

${ }^{46}$ Martin Gardner, ed., Lewis Carroll, The Hunting of the Snark: The Definitive Edition, with an Introduction by Adam Gopnik, New York: W.W. Norton, 2006, p. xxxii; see text 5.2.
} 
be the divine father of Alexander of Macedon, who was depicted on coins with the ram's horns of the Nilotic divinity curling out of his leonine tresses (hence Alexander's appellation in Qur'ānic literature as $d h \bar{u}$ 'l qarnain, "he of the horns twain").

Kharms mentions also the word kabala (1. 6). The poet was fascinated by magic and the occult, by Egyptian symbols (especially the ankh), and by the Hebrew alphabet and the Jewish Kabbala. ${ }^{47}$ In notebook 8 (18 October 1926-13 May 1927, I.139) he provides a careful diagram of the Kabbalistic Tree of Life, with the names of the sefirot transcribed into Cyrillic and translated into Russian; and in notebook 22, from the early 1930's, he lists the letters of the Hebrew alphabet, with their symbolism noted both in Cyrillic and in a private cipher (I, 400; III.147). In the latter notebook (I.416) he has a shorter list of the Hebrew letters, alongside which is the Tetragrammaton, an apparent experimental mutation of it, and the phrase ГАМ $3 \mathrm{Y}$ ЛИТЕЙВО, gam zu liteyvo, which is a transcription of an Ashkenazic pronunciation of the old Talmudic maxim Gam zû lə-tôvā, "This, too, is for the best." So Kharms has taken the template of the mythical geography of the Prologue to $R L$ and has widened its reach to include the Asiatic climes of mediaeval romance and the mysteries of the Kabbalah, whilst in his usage of kikat' deftly fusing the poetico-magicolinguistic practice of zaum' with the same springs of Russian folklore and mythology from which Pushkin had drawn. And how might Kharms have seen his own place within his fantastic landscape? Kharms and his fellow Чинари, "Chinars" (this neologism, used as a designation of their literary circle, may refer to the angelic ranks, Rus. chiny, in the mystical writings of Ps.-Dionysius the Areopagite on the structure of the Divine world) were convinced that entities from a world or worlds that abut on or overlap ours can appear as emissaries. ${ }^{48}$ So the idea of the lukomor'e as a transit-point of the Otherworld would not have seemed at all bizarre to him: Alexander's (?) island of Ammon, ships, perhaps a Kabbala in ruins like a sort of threedimensional text (unless he means the homonym, old Rus. кабала, a form of slavery or indebtedness), storms "on order", golden domes, the black earth, and Alyonya and the Pechenegs present the diffracted geography of a mythical realm beyond space and time into and out of which the mind travels; and one imagines Kharms at home in it.

\section{CONCLUSION.}

Pushkin's Prologue, immortally famous in every way a poem can be, and perfect as the Russian bard's every line was, has of course literally and figuratively echoed down the nearly two centuries since he wrote it. It is not surprising that later visionary geniuses of the Russian poetic art, perceiving the rich and strange intricacy beneath its bright and simple surface, have refracted its multiple meditations upon myth and story, poet and tradition, space and time and the joyful surprise that lies ever glimmeringly beyond. It can be, indeed, as lucid as you like or as deep as you choose to dive - a lively South Russian seashore where delightful creatures disport themselves around the Zaporozhian oak, or a sea of space and time lapping against a mystic shore where a poet seated by the World Tree draws his readers into a timely, multi-dimensional otherworld of transformation. One can enjoy the shimmering Voltairean surface or submerge oneself in Neoplatonist, Gnostic, Armeno-Irano-Aramaic Mandaean depths, or do both: Pushkin's art admits the dualities of aesthetic and intellectual, even spiritual, pleasure.

There is a final duality adumbrated in the poem. The Russian literature that all the world cherishes began with Pushkin, though it emerges from a written tradition, also, that is a thousand years old. The epic and mythology in the poem are fresh and new, the stuff of a highly self-conscious Romantic "discovery" of European antiquities. And Russia itself was the newest of the European state-empires: the sacrifice of Moscow and the victory over Napoleon in 1812, in a way, marked its entry into the politics of the continent's great powers far more decisively than the reign of Peter the Great. The Slavonic languages are excluded from some surveys of ancient tongues, on the arbitrary and misleading grounds that their written monuments do not predate the fifth century AD. Yet the Indo-European poetic arts were pre-eminently characterized by their orality: the Russians are equally an ancient people, kin to the Venedi of Tacitus; and

\footnotetext{
${ }^{47}$ Pushkin was aware of his own Ethiopian ancestry; and one of his prized possessions was a seal ring with a Hebrew inscription. He had some interest in the occult themes so popular among the Gothic writers of the late $18^{\text {th }}$ century; cf. his Queen of Spades, for instance.

${ }^{48}$ See Eugene Ostashevsky, tr., OBERIU: An Anthology of Russian Absurdism, Evanston, IL: Northwestern University Press, 2006, p. xxvii.
} 
their undeniably ancient language is steeped in the deep poetic structures of millennia. (In this essay one has touched upon the play of ved-and vid-, for example.) Pushkin's lightness and depth, his playfulness and seriousness together, reflect a duality of Russia as venerable sage and strong and cheerful youth, the nation's antiquity and modernity. Taken together these are the wholeness of life, the integrity of vision, the balance of time at whose center sit, talking, Pushkin and his Cat.

TEXTS.

1. Alexander Sergeyevich Pushkin (1799-1837).

1.1. Prologue to Ruslan and Ludmila (A.С. Пушкин, Полное собрание сочинений, т. 4, Москва: Изд. AH CCCP, 1937, c. 5-6: A.S. Pushkin, Complete Works, vol. 4, Moscow: Academy of Sciences of the USSR, 1937, pp. 5-6):

У лукоморья дуб зеленый;/ Златая цепь на дубе том:/ И днем и ночью кот ученый/Все ходит по цепи кругом;/ Идет направо- песнь заводит,/ Налево- сказку говорит.// Там чудеса: там леший бродит,/ Русалка на ветвях сидит;/ Там на неведомых дорожках/ (10) Следы невиданных зверей;/ Избушка там на курьих ножках/ Стоит без окон, без дверей;/ Там лес и дол видений полны;/ Там о заре прихлынут волны/ На брег песчаный и пустой,/ И тридцать витязей прекрасных/ Чредой из вод выходят ясных,/ И с ними дядька их морской;/ Там королевич мимоходом/ (20) Пленяет грозного царя;/ Там в облаках перед народом/ Через леса, через моря/ Колдун несет богатыря;/ В темнице там царевна тужит,/ А бурый волк ей верно служит;/ Там ступа с Бабою Ягой/ Идет бредет сама собой;/ Там царь Кащей над златом чахнет;/ Там русский дух... там Русью пахнет!/ (30) И там я был, и мед я пил;/ У моря видел дуб зеленый;/ Под ним сидел, и кот ученый/ Свои мне сказки говорил./ Одну я помню: сказку эту/ Поведаю теперь я свету...//

Дела давно минувших дней,/ Преданья старины глубокой. ${ }^{49}$

By the bow-curve of the seashore there is a green oak;/ A golden chain on that oak:/ And by day and night a Learned Cat/ Goes round constantly on the chain;/ He goes to the right — chants a lay;/ To the left - recites a tale.// Wonders are there: there a Forest Sprite wanders,/ A Mermaid sits upon the branches./ There on unknown paths/ Are the tracks of unseen beasts;/ A hut there on chicken feet/ Stands without windows, without doors;/ There wood and dale are full of visions;/ There at dawn roll in the waves/ Onto the empty, sandy shore,/ And thirty splendid Knights/ File out of the waters, bright,/ And with them their Seaborn Sire;/ There the Prince in passing/ (20) Takes prisoner the fearsome King;/ There in the clouds before the people/ Across forests, across seas/ The Wizard bears the Hero;/ There in a dungeon pines a Princess, / But a Brown Wolf serves her loyally;/ There a mortar with the Witch/ Wanders going by itself;/ There king Kashchei withers over his wealth;/ The Russian spirit is there... there is the aroma of Rus'!/ (30) And there was I — and the mead I drank;/ By the sea I saw the green oak;/ Sat beneath it, and the Learned Cat/ Told me his tales./ One I remember: this tale/ I shall recount now to society...// Deeds of days long gone,/ Traditions of deep antiquity.

1.2. У моря лукоморья стоит дуб, а на том дубу золотые цепи, и по тем цепям ходит кот: вверх идет- сказки сказывает, вниз идет- песни поет.

By the sea, the curving seashore, an oak stands, and on that oak are golden chains, and by those chains walks a cat: he goes up and recounts tales; he goes down and sings songs.

2. William BlaKe (1757-1827). Text from Milton (composed 1804-1811), in The Complete Poetry and Prose of William Blake, edited by David V. Erdman, commentary by Harold Bloom, Garden City, NY:

${ }^{49}$ I have included this couplet, a translation from "Carthon" in the Ossian of James Macpherson, partly because in the first edition of $R L$ it was both Prologue and Epilogue: true to the ancient form of ring composition, it concludes Canto VI. But the separate concluding couplet also allows one at least the fleeting feeling of the Prologue as a sonnet; cf. Scarlett Thomas' sonnet, a parallel in some respects to the Prologue, text 6.1. 
Anchor, 1982. Robin Hamlyn and Michael Phillips, William Blake, NY: Abrams, 2000, discuss the painting "The Sea of Time and Space" (pp. 192-193 and pl. 240) and agree with the interpretation advanced by Heppner, discussed above. The text from Milton in which Blake mentions the Sea of Time and Space, though, is not cited.

2.1. And all the Spectres of the Dead calling themselves Sons of God,/ In his Synagogue worship Satan under the Unutterable Name (p. 104, plate 11[12], lines 13-14).

2.2. The nature of Infinity is this: that every thing has its/ Own Vortex; and when once a traveller thro' Eternity/ Has passed that Vortex, he perceives it not roll backward behind/ His path, into a Globe itself enfolding, Like a Sun (p. 109, plate 15[17], lines 21-24).

2.3. First Milton saw Albion upon the Rock of Ages,/ Deadly pale, outstretch'd, and snowy-cold, stormcover'd - / A Giant form of perfect beauty, outstretch'd on the Rock/ In solemn Death: the Sea of Time and Space thunder'd aloud/ Against the Rock, which was enwrapped with the weeds of Death./ Hovering over the cold bosom in its vortex, Milton bent down/ To the bosom of Death: what was underneath soon seemed above,/ A cloudy heaven mingled with stormy seas in loudest ruin,/ But as a wintry globe descends precipitant, thro' Beulah bursting, / With thunders loud and terrible, so Milton's Shadow fell/ Precipitant, loud thund'ring, into the Sea of Time and Space (p. 109, plate 15[17], lines 36-46).

3. Velimir KhlebNiKov (1885-1921). Texts from the ed. Велимир Хлебников, Собрание сочинений в mрех томах, СПб: Академический проект, 2001 (Velimir Khlebnikov, Collected Works in Three Volumes, St. Petersburg: Academic Project, 2001), cited by vol. and page no. In an autobigraphical sketch of 1914, the poet notes that he was born 28 Oct. 1885 in the Astrakhan' steppe, and "in my veins there flows the Armenian blood of the Alabov [clan]" («в моих жилах есть армянская кровь (Алабовы)»).

3.1. (I, 61): Времыши - камыши/ На озере береге,/ Где каменья временем,/ Где время каменьем./ На берега озере/ Времыши, камыши,/ На озера береге/ Священно шумящие.

$(1907,1908)$

Reeds of time, blades of grass/ On the shore of the lake,/ Where the stones are time's means;/ And time, a thing of stone./ On the lake belonging to the shore,/ Reeds of time, blades of grass/ On the shore of the lake,/ Sacred sussurus.

(In my translation I have rendered Khlebnikov's invented vremyshi, a compound, pl., of vremya "time" and kamysh' "tall grass" as literally as possible, and have tried to retain the assonance of the final strophe. To convey the cultural markedness of tall grasses to Americans, Walt Whitman provides the echo. Khlebnikov himself was probably inspired to use these grasses as the incipit of his evocation of the mythical world by K.D. Bal'mont's Symbolist landscapes of the 1890's: the poem Kamyshi, with its echoes of Poe, and the famous Bezglagol'nost' ("Speechlessness"), with its strophe «Недвижный камыш. Не трепещет осока.» ("The grasses are motionless; the reeds do not stir.") Here is the looser, though more tuneful, rendering by Paul Schmidt, tr., Charlotte Douglas, ed., Velimir Khlebnikov, The King of Time: Selected Writings of the Russian Futurian, Cambridge, MA: Harvard Univ. Press, 1985, p. 16: "The streams of time/ On stone dreams,/ The rush of streams/ On time's stones./ Rustling sedge/ At the lake's edge-/ Reverent hush,/ Reverberant rush.”)

3.2. (I, 46-47): Русалка телом голубым/ Немоб осенних красоту/ Воспеть хотела./ Туда, о, к ней! Туда, о, к ним!/ И вмиг к реке! И вмиг в волну!/ Туда, где рень! Туда, где пена!/ Но где же цель? Но где же тело?/ Но где же плен? Но где полон?/ Она, она, о ужас слышу, — зеленая жена!/ И вопль ее, толпа испугом —/ О ужас, ужас, о сором!..// На простыне к высокому небу/ Русалочьего заманника подбрасывают.

(1907)

A mermaid with sky-blue body/ The beauty of autumnal mutenesses/ Wanted to extol in song./ There, to her; there, to them!/ Instantly into the river and the wave!/ There, where the shoal is; there, where the foam!/ But where is object; body, where?/ Where is captivity; the captive, where?/ She, she, I hear the 
fear-wife all green!/ And a frightened mob is her howling,/ O horror, horror and shame!/ They toss the mermaid's prey/ On a blanket high into the sky.

3.3. (I, 63): Видязь видений безликих/ Вероши в яви/ Есть узывностынь редкой мечты,/ В русалиях яви голубоши,/ Безмерной, бесценной, беспленной,/ Бестешной Мокоши/ Есть русалие хлябей мечты,/ Есть Русь хлябей домирного,/ Хлябей довещной черты/ Домирного мира.

The visioknight ${ }^{50}$ of visions faceless/ Of a thing of faith awake/ Is the hearkenfreezing of a rare dream,/ In the Rusaliences ${ }^{51}$ of skyblueness waking,/ Of boundless, priceless, uncaptured/ Mokosh ${ }^{, 52}$ light and unconsoled./ There is a Rusalience of the gulfs of dream,/ A Rus ${ }^{53}$ of abysses before the world,/ Of gulfs of the shape before form/ Of the world before it was made.

3.4. (I, 58): Россия забыла напитки,/ В них вечности было вино,/ И в первом разобранном свитке/ Восчла роковое письмо./ Ты свитку внимала немливо,/ Как взрослым внимает дитя,/ И подлая тайная сила/ Тебя наблюдала нехотя.

Russia forgot her potations:/ In them was the wine of eternity,/ And in the first scroll unrolled/ Fateful script she read./ You listened to the reading laxly mute/ As a child hears an adult out,/ And a stealthy secret power/ Regarded you against its own will.

3.5 (I, 63): Кто в славобе чародей, —/ Славодейное искусство/ Почитает, славянина/ Называя: соловей.

Who is wizard in matters of glory:/ His praise-crafter's art/ Naming the nightingale/ Declares: Slav. ${ }^{54}$

3.6 (III, 32):

\section{ИСКУШЕНИЕ ГРЕШНИКА}

... И были многие и многия: и были враны с голосом: «смерть!» и крыльями ночей, и правдоцветиковый папоротник, и врематая избушка, и лицо старушонки в кичке вечности, и злой пес на цепи дней, с языком мысли, и тропа, по которой бегают сутки и на которой отпечатлелись

\footnotetext{
${ }^{50}$ Khlebnikov's neologism, vidyaz', with vid- "see", patterned on vityaz', "knight", cf. Pushkin's Prologue, line 16. On Khlebnikov's invented vocabulary, see Наталья Перцова, Словарь неологизмов Велимира Хлебникова [Natal'ya Pertsova, Dictionary of the Neologisms of Velimir Khlebnikov], Wiener Slawistischer Almanach, Sonderband 40, Москва, 1995.

${ }^{51}$ Rosalie combines Latin Rosalia, a festival of roses and waters (cf. Gk. Anthesterion, and the Armenian Vardavar, or Feast of the Transfiguration, to which Vyacheslav Ivanov devoted a dreamily lyric poem, to which in turn Vahan Teryan testily replied in verses on the Armenian massacres that were going on at that very moment), with rusalka. Nabokov's Pnin thinks of Ophelia, the drowned maiden, the rusalka, in connection with Russian summer festivals when garlands of flowers were cast upon the river waters.

${ }^{52}$ A Slavonic god of the waters, cf. mok(r)-, "wet"; Khlebnikov connects the being to his other neologisms ending here in $-o s h$ '.

${ }^{53}$ Though many invoke Russia's archaic name, note in particular Pushkin's use of it in the Prologue: Tam russkii dukh,/ tam Rus'yu pakhnet!

${ }^{54}$ On the issue of Slav-slovo-solovei, see J.R. Russell, "Solov' $i$, solov' $i$," forthcoming in Festschrift Nina Garsoian of the St. Nersess Theological Review, 2006; Rus. tr. in Россия ХХI век, Москва, 2006.4, с. 156197 (Russia in the 21st Century, Moscow, 2006, no. 4, pp. 156-197). In his "star language" Khlebnikov asserted the connective identity Славянство-восход-звук: Слава слова и слава солнца. Сияние слов. Солнечная природа слов. "Slavonicity-ascent-sound: The glory of the word and the glory of the sun. The scintillation of words. The solar nature of words." See Barbara Lönnkvist, Universe in word: Poetics of Velimir Khlebnikov, Rus. tr. СПб: Академический Проект [St. Petersburg: Academic Project], 1999, pp. 70-71.
} 
следы дня, вечера и утра, и небокорое древо, больное жуками-пилильщиками, и юневое озеро и глазасторогие козлы, и мордастоногие дива, и девоорлы с грустильями вместо крылий и на любови вместо босови, и мальчик, пускающий с соломинки один мир за другим и хохочущий беззаботно, и было младенцекаменное ложе, по которому струились злые и буйные воды и пролетало низко над землей сомнениекрылая ласточка и пел влагокликий соловей на колковзором шиповнике, и стояла ограда из времового тесу, и скорбеветвенный страдняк ник над водой, и было озеро, где вместо камня было время, а вместо камышей шумели времыши. И зыбились грустняки над озером. И плавал правдохвостый сом, и давала круги равенствозубая щука, и толчками быстрыми и незаметными пятился назад - справедливость - клешенный рак. И шествовала времяклювая цапля и глотала лягушей с мировой икрой на приятноватых ногах, и был старец, возделывавший лжаное поле, и молодежеперый кур застыл перед проведенной чертой...

(1907)

(Paul Schmidt, tr., Ronald Vroon, ed., Collected Works of Velimir Khlebnikov, vol. II, Cambridge, MA: Harvard Univ. Press, 1989, p. 10: “A SINNER'S SEDUCTION. There were many of them, many of them blackbirds with nightwings saying 'Death!' and truthflower ferns and a timethatch cottage and the face of an oldwomer in eternity's tripes and a snapping hound on a chain of days whose tongue was thought and there was a path, and on the path one day followed another and left behind prints of daytime and evening and morning, and a skybarked tree eaten up by fiddle beetles and a youngering lake and horneyed goats and astonishing centipusses and girleens with whinings where they might have had wings and love instead of lore, and a boy setting one world after another loose from a straw and laughing for he cared about nothing and was a stretch of youngstones too and over it the swift and snapping water ran..." $)^{55}$

4. DANIIL KHARMS (born ДАНИИЛ ИвАНОВИЧ ЮвАЧЁв, DANIIL IVANOVICH YuVACHEV, 1905-1942). Kharms a friend of Khlebnikov's and a member of the Орден заумников, “Order of Transrationalists”practitioners of zaum'. Texts from (I) Даниил Хармс, Полное собрание сочинений: Записные книжки, дневник, книга 1, СПб: Академический проект, 2002 (Daniil Kharms, Complete Collected Works: Notebooks, Diary, vol. 1, St. Petersburg: Academic Project, 2002); (II) Поэты группь «ОБЭРИУ», под ред. М.Б. Мейлаха, Библиотека поэта, большая серия, 3-ье изд., СПб: Советский писатель, 1994 (M.B. Meilakh, ed., Poets of the Group “OBERIU”, Poet's Library, Major Series, 3 rd ed., St. Petersburg: Sovetskii Pisatel', 1994). For Kharms' cipher, Kabbalistic diagram, list of Hebrew letters, Osiris-symbol, etc., see I and Рисунки Хармса, сост. Ю.С. Александров, СПб: Изд-во Ивана Лимбаха, 2006 (Kharms' Drawings, compiled by Yu. S. Alexandrov, St. Petersburg: Ivan Limbakh, 2006).

\section{1 (I.45):}

(Лист 11 oб./ Fol. 11b) Надо кикать лукоморье/ для конюшенной езды/ из за острова Амонья/ винограда и узды/ и рукой её вертели/ и руина кабала/ и заказаны метели/ золотые копола/ и чего-то разбедянит/ (10) кацавейкою в дали / а на небе кораблями/ пробегали корабли/ надо кикать чернозёмом/ а накикавшись в трубу/ кумачевую Аленю/ и руину кабалу/ не смотри на печенегу/ не увидиш(ь) (кабалу) коче (2 нрзб./ two lines illegible) (Лucm 12/Fol. 12a) а в зазёрах другими азарными/ (20) телеграммою на верстах/ александру так и кажется/кто-то кикает за кусты/ (от ура до) целый день до заката вечера/ от парчи до (закат) малевок князевых/ встанут (нелюди?) изувечено/ томами синими Полуазии/ Александра козят араби (sic!)/ целый остров ему бовекой/ Александр козит корабль/ (30) минотавра и человека/ И апостола зыда мокром/ через шею опракинул (sic!)/ в море остров в море Потемье/ в море шарка финикии

"The curving shore deserves a coo/ For riding from the stable/ Out from the isle of Ammon/ Where there are grapevine growing, reins./ She was spinning with her hands, / And there the ruins of Kabbala are. ${ }^{56}$ /

\footnotetext{
${ }^{55}$ Vasilii Kamensky gave Khlebnikov an advance for this piece, recognizing in it a completely new and exciting poetics. The poet promptly spent the money at a Caucasian restaurant, hiring musicians and dining on shashlik (see София Старкина, Велимир Хлебников, король времени: Биография, СПб: Вита Нова, 2005, c. 75: Sofia Starkina, Velimir Khlebnikov, the King of Time: A Biography, St. Petersburg: Vita Nova, 2005, p. 75).

${ }^{56}$ The Rus. kabala has two meanings: either Jewish Kabbala, or, with the very same spelling, an old Muscovite term for indentured slavery. Given Kharms' interest in Judaica and esoterica, I have opted for the former meaning.
} 
Snowstorms meanwhile have been hired/ To go with golden onion domes./ And someone far away/ (10) In a fur-fringed vest was crying woe,/ While in the sky passed/ Ships in the shapes of ships./ One has to crow like chernozem, ${ }^{57} /$ And having crowed into the trumpet one's fill,/ red-bunting-decked Alyonka/ And the Kabbalistic ruins, too,/ Stop looking at that Pecheneg:/ You won't see Kabbala,/ Nomadic... ${ }^{58} /$ While in the sudden lakes (?) ${ }^{59}$ other unexpected/ (20) Telegrams on the line,/ It seems to Alexander/ That someone behind the bushes crows/ (From hurrah) at break of day to evening — when the sunshine goes - / From embroideries in silk to princes' (sunset) canvasses in oil,/ Blue tomes of half of Asia/ Full of monsters ${ }^{60}$ will arise deformed./ in blue tomes of half of Asia/ Arabs torture Alexander,/ and he's got half an isle;/ Alexander leaps to his ship/ (30) Dragging man and minotaur on board./ But the Apostle itches, damp,/ Throws the isle over his shoulder into the sea, the sea of Darkness,/ Where date palms scrape..."

4.2. Kharms published a longer and revised version of the poem (4.1), completed in August or September 1925: it is reprinted in II, No. 257, pp. 484-487. On its relation to the foregoing it may be apposite to quote the general observation of М.О. Чудакова, Рукопись и книга, Москва: Просвещение, 1986, с. 113 (М.О. Chudakova, The Manuscript and the Book, Moscow: Enlightenment, 1986, p. 113): "The printed work in a new edition is not infrequently subjected to the author's revision. From another point of view, that which had seemed to the author a preliminary variant of a poem now at a certain moment takes its place alongside the later variant. They seem to share equal rights. (Mandelstam's mature period, as is well known, is notable for such a relationship: to those who valued his earlier verses, the new ones seemed incomplete and not perfected.) The tendency to see in the poet's 'creative workshop' a necessarily progressive movement from the less successful to the improved played its role here, as it seems." The longer poem Kharms published is not necessarily the better or the more polished; I would argue that it stands in relation to the tighter, earlier poem much as the concisely epic Drachenkampf "Jabberwocky" (text 5.1) of Lewis Carroll, whose work Kharms loved - and whose absurdist experiments with language and theme must be considered a major inspiration of Kharms' work - does to the longer Hunting of the Snark (discussed in 5.2), which borrows transrational neologisms from the former. ${ }^{61}$

5. Lewis Carroll (Rev. Charles Lutwidge Dodgson, 1832-1898). After listening to "Jabberwocky" in Through the Looking Glass, Alice exclaims to Humpty Dumpty "It seems very pretty, but it's rather hard to understand!" And in fact Carroll uses 28 neologisms (four of which are actually revivals of obscure words) in the poem of 24 lines, by the expert count of the English lexicographer Eric Partridge. ${ }^{62}$ This density of odd new word-creatures — some of which describe, indeed, fictional animals — recalls that of Pushkin's folkloric beings in the Prologue to $R L$; and it lends Jabberwocky the same pleasing compactness as a self-enclosed magic world. Carroll called the inventions that pack two meanings into a single word, portmanteaux. These occur in natural languages (e.g., blot, from black and spot or dot); and another feature of the binary quality of the neologisms is echoic reduplication. Thus, a sword goes snicker-snack ("snicker" means a knife blade). Partridge gamely attempts to explain the words Humpty Dumpty does not: manxome, for instance, is a rather overstuffed overnight bag with a maniac, a Manx (odd tailless cat, presumably), and the adjective fearsome. The Jabberwock itself is to be understood as an echoic dialectal compound of "jatter" (shatter) and "whacker" (something enormous).

Why do this? Aside from the sheer delight of creative expression and the pleasure of vision communicated to the reader, it would seem that words combining the usual and the strange, or terms that seem half-known but just outside the perimeter of everyday sight, are meant to expand one's capacity to

\footnotetext{
57 The rich Russian “black earth” of the nation's breadbasket.

${ }^{58}$ Two lines in the manuscript are illegible: I've taken a stab at "nomadic" for Rus. *koche... because the Pechenegs were nomads.

${ }^{59}$ Rus. v zazyorakh: preverb za- + loc. pl. of ozero?

${ }^{60}$ Rus. *nelyudi (restored), "unhumans", which I understand as exotic monsters, rather than a derogation, as in Marina Tsvetaeva's designation in 1938 of the German fascist invaders of Czechoslovakia as unhumans (Rus. нелюдей, gen. pl.) in the sense of reprobate subhumans.

${ }^{61}$ «Вот мои любимые писатели: Гоголь, Прутков, Метринк, Гамсун, Едвард Лир, Люис Кэрроль» (Хармс, Зап. Книжки, II, с. 196, 14 ноября 1937): "Here are my favorite writers: Gogol, Prutkov, Maeterlink, Hamsun, Edward Lear, Louis Carroll” (Kharms, Notebooks, II, p. 196, 14 November 1937).

${ }^{62}$ See his essay "The Nonsense Words of Edward Lear and Lewis Carroll," Here, There, and Everywhere: Essays Upon Language, London: Hamish Hamilton, 1950, pp. 162-188.
} 
perceive, to enable one to accept the impossible as real. This is what makes a fantasy successful. So, in the third-dimensional world we cannot see grasses made of time, or wings whose motive power is the emotion of sorrow; but the Khlebnikovian portmanteaux vremysh' and grustil'ya transport one into a fifth dimension through the skillful manipulation of the conventions of language. In comparing the setting of the Prologue to $R L$ to the mysterious landscape of William Blake's painting and, more remotely, to the sacred geography of the Mandaean ritual space, I have deliberately violated the distinctions generally drawn between profane and sacred modes of representation and expression, since a strict division of these categories impede the study of mythopoesis, an activity related to both. And indeed the use of invented or nonsense language in ancient religion was believed to enable the mind to grasp the ungraspable paradoxes of the supernatural. In the Gnostic text Thunder, Perfect Mind, for instance, the Goddess declares, "I am the hearing which is attainable to everyone and the speech which cannot be grasped. I am a mute who does not speak, and great is my multitude of words." If that deity is one's reality, muses a modern scholar of the text, then how do you show you've learnt her speech? ${ }^{63}$ The answer is, you alter your own language, introducing voces mysticae, glossolalia, and neologism. But perhaps the strongest vindication of one's method allowing application of religious material to the study of a secular text may be found in the converse evocation of Lewis Carroll by a historian of early Christianity in a study of proto-Pentecostal speech: "... denial of the relation between Christian and magical prayer overlooks the main problem- to explain, not why the spirit spoke to the churches, but why it spoke to them in jabberwocky" [emphasis mine]. ${ }^{64}$ It is significant that Kharms had an abiding interest in various kinds of magic and mysticism, all of which employed the manipulation of letters and sounds and the use of obscure and barbarous words. His matrix of interests overlapped considerably with those of the early Christians, magicians, and Gnostics.

But were Carroll or Kharms to require an advocate of their own literary jabberwocky, they could not have found a more eloquent one than their brother poet Hart Crane: when in 1926 Harriet Monroe, the Editor of Poetry, expressed bafflement at his poem "At Melville's Tomb”, he wrote back, "... as a poet I may very possibly be more interested in the so-called illogical impingements of words on the consciousness (and their combinations and interplay in metaphor on this basis) than I am interested in the preservation of their logically rigid significations at the cost of limiting my subject matter and perceptions involved in the poem." 65

\section{1. "Jabberwocky”, from Through the Looking Glass.}

'Twas brillig,/ and the slithy toves/ Did gyre and gimble/ in the wabe;/ All mimsy were/ the borogoves,/ And the mome/ raths outgrabe./ "Beware the Jabberwock, my son!/ The jaws that bite,/ the claws that catch!/ Beware the Jubjub bird,/ and shun/ The frumious Bandersnatch!"/ / He took his vorpal sword/ in hand:/ Long time the manxome/ foe he sought_/ so rested he by/ the Tumtum tree/ and stood awhile/ in thought.// And as in uffish thought he stood,/ The Jabberwock,/ with eyes of flame,/ Came whiffling through/ the tulgey wood,/ And burbled/ as it came!// One, two! One, two!/ And through and through/ The vorpal blade/ went snicker-snack!/ He left it dead,/ and with its head/ He went/ galumphing back.// "And hast thou slain/ the Jabberwock?/ Come to my arms,/ my beamish boy!/ O frabjous day!/ Callooh! Callay!"/ He chortled in his joy.// 'Twas brillig,/ and the slithy toves/ Did gyre and gimble/ in the wabe;/ All mimsy were/ the borogoves,/ And the mome/ raths outgrabe."

5.2. The Hunting of the Snark, 1876. (Page references to: Martin Gardner, ed., Lewis Carroll, The Hunting of the Snark: The Definitive Edition, with an Introduction by Adam Gopnik, New York: W.W. Norton, 2006.) Carroll in his Preface to his Agony in Eight Fits explains, “...this poem is to some extent connected with the lay of the Jabberwock" (p. 10). Thematically it is also a quest for a monster; but the hunters do not catch the Snark, nor is it clearly described or describable. It is also likely to become a Boojum and catch

${ }^{63}$ See Patricia Cox Miller, "In Praise of Nonsense," in A.H. Armstrong, ed., Classical Mediterranean Spirituality: Egyptian, Greek, Roman, NY: Crossroads, 1986, p. 482.

${ }^{64}$ Morton Smith, Clement of Alexandria and a Secret Gospel of Mark, Cambridge, MA: Harvard University Press, 1973, p. 232, who points out that recorded Christian glossolalic lexical items are similar to pagan ones, and that correspondingly in the ostensibly pagan corpus of the Greek magical papyri, the divinity $I A \bar{O}$ (a Greek rendering of the Hebrew Tetragrammaton) is the most common, followed by Adōnaï, a transcription of the Hebrew for "the Lord".

${ }^{65}$ Langdon Hammer, ed., Hart Crane: Complete Poems and Selected Letters, NY: Library of America, 2006, pp. 165 and 803 n. 
them instead; and a number of commentators have suggested that the poem deals with the insanity of quotidian concerns and the horror of the approach of oblivion, of the senseless end of one's life. But Snark is just as likely an absurd and surreal work whose only logic is that of the shifting forms, dimensions, and rules of a dream. This much longer poem is largely in standard English, with the only neologisms snark and boojum; but Carroll reuses a number of invented words from Jabberwocky: in his Preface the author notes the proper pronunciation of slithy toves and borogoves; and in the body of the text we find beamish (p. 36), uffish (p. 41), galumphing and Jubjub (p. 45), outgrabe (p. 49), bandersnatch (p. 63), frumious (p. 65), and mimsiest, the superlative of the adj. mimsy (p. 65).

A reader who enjoys the clean thematic lines and consistent invented speech of Jabberwocky, from Carroll's earlier period, may like less this longer, darker, less manageable product of a later stage of the writer's career. Jabberwocky has the geographical and temporal integrity of a quest narrative: it starts in a sort of crepuscular (brillig) bower (wabe); after the father's instructions, the youth goes forth into the dense, dark forest (tulgey wood). He rests against a Tumtum tree at almost the exact center of the poem, too: compare Pushkin's Yggdrasil! — and when, having slain the Jabberwock, he rides swiftly (galumphs) back, all is now bathed in morning light. The boy himself is aglow (beamish), and the day is splendid (frabjous). By contrast, the hunters of the Snark set out with a blank map and at the end the Baker vanishes: all is deliberately anti-logical, so when the Pig is charged with desertion, for instance, it pleads an alibi in mitigation (p. 107)!

6. SCARlett Thomas (1972-). Text from The End of Mr. Y, Orlando, FL: Harcourt, 2006, pp. 26-27. The novel deals with a young university lecturer of English at a provincial university in Britain: her name, Ariel, recalls that of Prospero's angelic sprite in The Tempest of Shakespeare. Ariel is writing a thesis on an obscure $19^{\text {th }}$-century novelist, T.E. Lumas, whose forgotten book, The End of Mr. Y, contains a recipe for a potion compounded of holy water and a homeopathic drug that takes the hapless hero Mr. Y - and can transport the reader - in a drugged trance called "telemancy" into a sort of fifth-dimensional noösphere called the "Troposphere", where one has telepathic connections to other people. Thomas includes large portions of the fictive novel in her text, including the Prologue (text 6.1), a sonnet in iambic pentameter whose geography and mythic otherworldliness reminded me strongly of the Prologue to $R L$. It is as markedly and eerily depopulated as Pushkin's landscape is crowded with strange beings. At the end of both Troposphere and novel is a Garden of Eden with its Tree, to which the heroine and her appropriately named lover Adam repair. Spatially, the poem can be plotted as seashore on the left, then forest with, among other things, a cave (cf. Blake's "Sea of Time and Space" and De Antro Nympharum) and an oak (Pushkin, also the twin-trunked tree at the center of Blake's painting). There is a cabin (though not on chicken's feet) and a key. The scene is time-wrought: this recalls Khlebnikov's Futurian refraction of Pushkin's mythic landscape, and Kharms' subsequent homage to it. The implication is that place=time=thought, the last being the determinant of duration: we are in the world, that is, that includes sea of time and space but is not submerged within the latter itself.

From a previous novel by Thomas, one learns she has been interested in higher mathematics, cryptography, and the Voynich manuscript with its unknown script, fanciful drawings, and associations with the magical and the occult. (John Dee, court astrologer to queen Elizabeth I, and Athanasius Kircher after him, owned the book; and its authorship is attributed, probably wrongly, to Roger Bacon.) One might compare to this matrix of interests the obsession of Daniil Kharms with Kabbala and the Hebrew language, his monograms and symbols based on Egyptian hieroglyphs, his cosmological drawings, and his frequent use of ciphers. (The one he used most often is a substitution script of his own invention whose characters are drawn from a variety of sources, including Chinese and Japanese, the Samaritan form of Hebrew, and an alphabet based on alchemical and astrological signs that has been employed by occultists for centuries, most recently in the "Cipher MS." of the Golden Dawn group to which W.B. Yeats belonged.) Thomas and Kharms also share an interest in non-Euclidean mathematics and the fifth dimension: Kharms' notebooks are full of mathematical formulae and speculation.

The structural and thematic parallels to Pushkin's Prologue to $R L$ seemed striking to me, all the more so because text 6.1 is the sole passage in verse in Thomas' novel. I think sea, empty space, and dense forest is a symmetrically pleasing triadic composition, one often encountered in nature, whose multiple possible symbolisms make it attractive as a setting for an imaginative, mythopoetic writer, particularly one like Thomas whose set of interests matches so closely that of Kharms - the Russian who responded so creatively to Pushkin's poem, his imagination fertilized by the linguistic experiments of his own 
countryman, Velimir Khlebnikov, and of Thomas', Lewis Carroll. Rather than speculate as to whether the kinship I perceived was a case of filiation or of parallel creative vision, I wrote to ask Prof. Thomas whether she knew the Russian writers, and received a gracious reply by electronic mail on Friday, 3 November 2006, 2:31 PM, which I cite in part herewith: "To answer your questions... No, I am ashamed to say that I have never read Pushkin, and so the echo is accidental. I've never been entirely sure why I decided to have Lumas introduce his novel in verse. I remember at the time thinking I'd cut it if anyone pointed it out; but I was rather fond of it and since no one said anything, I left it in... I was reading Thomas Hardy and Edgar Allan Poe at the time; I remember that. I have always been very interested in Blake. You're more than welcome to quote me if I say/have said anything interesting enough. All I can think of now is that something of Pushkin has leaked into my part of the Troposphere, and I've picked it up unconsciously. But then I'd be believing in my own novel, and that would never do...!" This leaves at least the possibility of inspiration by Blake's painting; but more likely we deal with an independent vision conditioned in part by the multiple factors mentioned above.

6.1. "PROLOGUE. I see ahead a time-wrought shore;/ A fishing boat lifts on a wave;/ No footprints on the sandy floor,/ Beyond - an unfamiliar cave.// Or — forest tree'd with oak and yew/ A dark mare waits to carry me,/ Where nothing stirs yet all is true,/ A cabin door, and here- the key!// Perhaps I'll wander in a field,/ With poppy-flush on carpet green:/ However thought has been concealed/ No sleeper's eye can now undream.// In any place that I take flight/ The dark will mutate into light." 